\title{
Recent biomonitoring reports on phosphate ester flame retardants. A short review
}

\author{
Anne Marie Saillenfait ${ }^{1} \cdot$ Sophie Ndaw ${ }^{1} \cdot$ Alain Robert $^{1} \cdot$ Jean Philippe Sabaté $^{1}$ \\ ${ }^{1}$ Institut National de Recherche et de Sécurité, Rue du Morvan, CS, 60027, 54519 Vandoeuvre Cedex, \\ France
}

Anne Marie Saillenfait

Tel.: + 3383502039 .

Email address: anne-marie.saillenfait@inrs.fr

\begin{abstract}
Organophosphate triesters (PEFRs) are used increasingly as flame retardants and plasticizers in a variety of applications, such as building materials, textiles, and electric and electronic equipment. They have been proposed as alternatives to brominated flame retardants. This updated review shows that biomonitoring has gained incrementally greater importance in evaluating human exposure to PEFRs, and it holds the advantage of taking into account the multiple potential sources and various intake pathways of PEFRs. Simultaneous and extensive internal exposure to a broad range of PEFRs has been reported worldwide. Their metabolites, mainly dialkyl or diaryl diesters, have been used as biomarkers of exposure and have been ubiquitously detected in the urine of adults and children in the general population. Concentrations and profiles of PEFR urinary metabolites are seen to be variable and are highly dependent on individual and environmental factors, including age, country regulation of flame retardants, and types and quantities of emissions in microenvironments, as well as analytical procedures. Additional large biomonitoring studies, using a broad range of urinary diesters and hydroxylated metabolites, would be useful to improve the validity of the biomarkers and to refine assessments of human exposure to PEFRs.
\end{abstract}

\section{Keywords}

Flame retardant $\cdot$ Organophosphates $\cdot$ Exposure assessment $\cdot$ Human biomonitoring $\cdot$ Health 


\section{Introduction}

Organophosphorous flame retardants are one of the most common groups of flame retardants (FRs). They primarily consist of organophosphate triesters (PEFRs). The total global consumption of organophosphorous compounds used as FRs was estimated to be about 207000 tons in 2004. In 2006, chlorinated phosphate and non-chlorinated organophosphorous FRs represented 11 and $10 \%$ of FR consumption in Europe, respectively (NEG, 2009; Arcadis EBRC, 2011; EFRA, 2007). Since the early 2000s, brominated flame retardants such as certain polybrominated diphenyl ethers (PBDE), have been progressively phased out or seen their use restricted in many regions of the world (e.g., North America, Japan, and Europe), because of their bioaccumulation, persistence, and potential health effects. The halogen-free PEFRs are considered as possible alternatives to PBDE, and their production and use have been increasing over the past few years. PEFRs are also applied as plasticizers in polymers such as PVC (e.g., aryl phosphates), cellulosic fibers, polyurethane foams (e.g., chlorinated phosphate), and engineering plastics (e.g., polycarbonate/acrylonitrile butadiene styrene-PC/ABS, and polyphenylene oxide/high impact polystyrene-PPO/HIPS). Other applications of phosphate esters are as anti-foam agents, additives in hydraulic fluids, and lubricants. PEFRs have a broad application field and are extensively used alone or in combination with other FRs in a variety of industries, including plastics, furniture, textiles, construction, electrical engineering and electronics, transportation (e.g., road and rail vehicles), and the petroleum industry (NEG, 2009; ATSDR, 2012). Triphenyl phosphate (THPP) is also present in personal care products such as nail polish (Mendelsohn et al., 2016).

PEFRs are frequently applied as chemical additives and they are not chemically bound to the polymers (i.e. unlike reactive FRs). They can be released from treated industrial and commercial products by abrasion, leaching and/or volatilization during their lifetime. They have been detected in a wide range of environmental samples around the world (e.g., indoor dust) and concern about human exposure to PEFRs is increasing. In addition, some recent epidemiological studies have suggested that certain PEFRs may have possible health effects, such as interference with endocrine and reproduction functions. Tris(2-chloroethyl) phosphate (TCEP), tris(1,3-dichloro-2-propyl) phosphate (TDCIPP), and tris(2,3-dibromopropyl)phosphate (TDBPP) are listed as carcinogenic substances under California's proposition 65 (OEHHA, 2017). In Europe, several PEFRs have been classified as substances suspected of causing cancer (e.g., TCEP, TDCIPP, tributyl phosphate - TNBP) and/or that may damage fertility (e.g., TCEP, tri-ortho-cresyl phosphate-ToCP) (ECHA, 2018).

While the occurrence of PEFRs in indoor dust has been extensively described across the world, less is known about internal exposure to PEFRs in humans. Several human studies have used urinary biomarkers of PEFRs to monitor exposure to these FRs among workers and the general population.

This short review compiles the available data on PEFRs in human urine published from 2011 to May 2018. A comprehensive search was performed in the Pubmed database using the search terms "organophosphate flame retardant" and "exposure", or "flame retardant" and "urine". Only full text articles were reviewed. Studies were included if the PEFRs were measured in a biological matrix (e.g., urine, hair, milk). There were no restrictions on the size and age of the study population, geographical region, or study design (e.g., pooled data).

\section{Environmental occurrence and routes of exposure}

PEFRs have been found worldwide in diverse outdoor environments, including river water, groundwater, and wastewater, with individual concentrations ranging from several $\mathrm{ng} / \mathrm{l}$ to tens of $\mu \mathrm{g} / \mathrm{l}$ (Van der Veen et al., 2012; Wei et al., 2015; Ali et al., 2017). They have been ubiquitously detected in 
floor and surface dust from various indoor environments, including private houses, vehicles, and various public and work places (e.g., offices, daycare centers, electronic equipment stores and recycling plants, and hospitals). PEFRs concentrations in floor and surface dust were in the range of $0.02 \mathrm{ng} / \mathrm{g}$ to tens of $\mu \mathrm{g} / \mathrm{g}$. The concentrations of PEFRs measured in indoor air were generally around tens to hundreds of $\mathrm{ng} / \mathrm{m}^{3}$. Higher PEFR levels in indoor air or dust have occasionally been reported in occupational settings (e.g., recycling of electronics) or microenvironments (e.g., cars) (Wu et al., 2016; Ali et al., 2017; Zhou et al., 2017; Bello et al., 2018; Björnsdotter et al., 2018). Concentrations in outdoor air are approximately 1 to 4 orders of magnitude less than in indoor air (Wei et al., 2015). The ubiquity of PEFRs in the environment indicates that the general population is likely to be exposed to several of these chemicals, through multiple sources, on a daily basis.

PEFRs can enter the human body via several routes. Recent studies have shown that dermal absorption may contribute substantially to the total body burden of PEFRs (Abdallah et al., 2016; Mendelsohn et al., 2016; Liu et al., 2017; Bello et al., 2018; Frederiksen et al., 2018). Ingestion of dust and dermal exposure to dust and treated materials (e.g., clothes and furniture) are considered primary sources of exposure to PEFRs. For volatile or semi-volatile PEFRs (e.g., TCEP, tris(1-chloro-2propyl) phosphate - TCIPP), air and suspended particles inhalation may be a significant intake pathway (Schreder et al., 2016; Xu et al., 2016; He et al., 2018c). Ingestion of contaminated food (e.g., by migration from plastic packaging) may contribute to oral intake of PEFRs, but its contribution appears to vary substantially between compounds, as well as between and within populations (Zhang et al., 2016; Zheng et al., 2016; Xu et al., 2017; Poma et al., 2017, 2018).

\section{Human health effects}

The toxicological profiles of halogenated and non-halogenated PEFRs have been reviewed by several (environmental) agencies, in particular to evaluate their suitability as alternatives for PBDE FRs (NEG, 2009; ATSDR, 2012; Van den Eede et al., 2012; US EPA, 2015; Ministry of Environment and Food of Denmark, 2016). Assessments almost entirely relied on experimental studies. Critical effects were found to differ from one compound to another. A few PEFRs were identified as being toxic to the male reproductive system (i.e. TCEP, TDCIPP, ToCP), potentially carcinogenic (i.e.TCEP and TDCIPP), and/or toxic to specific organs (i.e. kidney for TCEP). Because of their toxic potential, the chlorinated PEFRs TCEP and TDCIPP are presently subject to regulations in several countries (mainly Northern America, Europe, Japan) (OEHHA, 2017; Canada Safety Consumer Act, 2018; ECHA, 2018). The US EPA has established an oral reference dose of $0.01 \mathrm{mg} / \mathrm{kg} /$ day for TCIPP, TEHP and TNBP; $0.02 \mathrm{mg} / \mathrm{kg} / \mathrm{day}$ for TmCP and TDCIPP; and $0.007 \mathrm{mg} / \mathrm{kg} /$ day for TCEP (US EPA, 2017).

Despite the increasing use of a wide range of PEFRs and the ubiquitous exposure to PEFRs among the general population, human data on the potential health effects of PEFRs are still limited, especially regarding long term exposure and the risks for children. The epidemiological studies published since 2010 mainly addressed respiratory outcomes (asthma, rhinitis), and endocrine and reproductive effects (Table 1). Results of a few studies have raised concern about the possible association between exposure to some PEFRs, and alteration of thyroid hormone regulation and male reproduction (e.g., sperm quality) (Meeker et al., 2010; Meeker et al., 2013a; Hoffman et al., 2017c; Preston et al. 2017; Soubry et al., 2017; Carignan et al., 2018a). However, at present, there is not enough consistent information from which to draw firm conclusions about the adverse health effects of PEFRs (as a class or specific) in humans. 
The isomer ToCP has proven to be neurotoxic and to inhibit both cholinesterase and neuropathy target esterase (NTE) activity (NEG, 2009; ATSDR, 2012; Van den Eede et al., 2012; US EPA, 2015; Ministry of Environment and Food of Denmark, 2016). Worldwide, it has been associated with numerous cases of delayed neuropathy and paralysis of the extremities in humans (Petroianu et al., 2016). Consequently, there has been a significant reduction in the commercial use of ToCP, e.g., in aircraft engine oil.

\section{Biomarkers of exposure}

\section{Cholinesterase activity}

The neurotoxic properties of ToCP have mainly been attributed to its metabolite cresyl saligenin phosphate. This reactive intermediate binds covalently to a serine moiety of butyrylcholinesterase in blood. The resulting adducts can be determined by mass-spectrometry and have been proposed as a biomarker for measuring exposure to ToCP (Schopfer et al., 2014; Tacal et al., 2014; Johnson et al., 2015). In addition, the American Conference of Governmental Industrial Hygienists (ACGIH) recommended erythrocyte cholinesterase activity as a biological exposure index (BEI) for ToCP. However this biomarker is not specific and can be inhibited by other OPs, such as organophosphorous pesticides (NEG, 2009; ATSDR, 2012).

\section{Urinary biomonitoring}

Urinary PEFRs or their metabolites appear to be the preferred non-invasive biomarkers for identifying and quantifying human exposure to PEFRs. They provide integrated information on total body burden, covering all types of sources and exposure pathways (i.e. inhalation, dermal absorption, and oral uptake), and they can be used to quantify an individual's exposure.

\section{Diester metabolites}

Information on the metabolism of PEFRs in humans is still limited and there are differences in the information available for different compounds. A common metabolic pathway has been proposed for the three types of PEFR triesters, i.e. trialkyl, triaryl, and trihaloalkyl/aryl phosphate esters. This was mainly based on in vivo studies in rodents and in vitro studies using human hepatocytes or liver fractions (Ballesteros-Gomez et al., 2015a and b; Hou et al., 2016; Van den Eede et al., 2013a, 2015a, $2016 \mathrm{a}, \mathrm{b}$ and c). The first steps in the biotransformation of these triesters lead to the rapid formation of diesters or monoesters by hydrolysis of one or two ether bonds between the phosphate group and the substituent, and to a variety of hydroxylated metabolites that undergo glucuronide and sulfate conjugation. Indeed, several dialkyl or diaryl phosphates have been detected in human urine, including bis(2-chloroethyl) phosphate (BCEP), bis(1-chloro-2-propyl) phosphate (BCIPP), bis(1,3-dichloro-2propyl) phosphate (BDCIPP), dibutyl phosphate (BNBP), and diphenyl phosphate (DPHP) (Table 1). These diesters are expected to be important and stable metabolites of TCEP, TCIPP, TDCIPP, TNBP, and triphenyl phosphate (TPHP), respectively (Table 2). Hence, most biomonitoring studies have focused on the determination of dialkyl or diaryl phosphate metabolites in urine to quantify human exposure levels to PEFRs.

However, there have been concerns regarding the use of urinary DPHP as a biomarker of exposure levels of the parent TPHP. DPHP may lack specificity since other aryl organophosphate esters containing at least two phenyl substituents [e.g., bisphenol A bis(diphenyl phosphate) and resorcinol bis(diphenyl) phosphate] have the potential to form DPHP after being hydrolysed and may contribute to DPHP urinary levels (Ballesteros-Gomez et al., 2015b; He et al., 2018a). In addition, 
DPHP itself is currently a commercially available product (e.g., as catalyst for resin manufacturing). Therefore, Van den Eede et al. (2016b) recommended using DPHP as a biomarker of aryl-PFRs rather than of TPHP only. In contrast with TPHP, the production of DPHP from 2-ethylhexyl diphenyl phosphate by human serum hydroxylase in vitro was found to be minor and thus it was not considered to be likely confounding factor (Van den Eede et al, 2016b).

Other metabolites

A few hydroxylated metabolites of PEFRs have recently been identified in urine samples from adults and children (Dodson et al., 2014; Van den Eede et al., 2015b; Hammel et al., 2016; Kosarac et al., 2016; Su et al., 2016; Bui et al., 2017; He et al., 2018a; Hoffman et al., 2017a, 2018; Phillips et al., 2018; Völkel et al., 2018). Urinary bis(2-butoxyethyl)-(2-hydroxyethyl) phosphate (BBOEHEP) was used to monitor exposure to tris(2-butoxyethyl) phosphate (TBOEP) (Van den Eede et al, 2015b; He et al., 2018a; Völkel et al., 2018). Hydroxylated metabolites of TPHP (i.e. 4-hydroxyphenyl diphenyl phosphate, 4-hydroxyphenyl phenyl phosphate), have been considered as potential specific urinary biomarkers of TPHP exposure (Van den Eede et al., 2013a, 2015b; Dodson et al., 2014; Su et al., 2016). However, they were only occasionally detected, and at very low levels, in human urine samples (glucuronide and sulfate conjugates, or the sum of free form and conjugates) (Van den Eede et al., 2015b, 2016b; Su et al., 2016). In several studies, the hydroxylated metabolite of TCIPP, bis(1-chloro2-propyl) 1-hydroxy-2-propyl phosphate (BCIPHPP), appeared to be a major urinary metabolite and therefore a candidate biomarker of human exposure to this PEFR (Van den Eede et al., 2015b; Butt et al., 2016; Hammel et al., 2016; Hoffman et al., 2017a; Bello et al., 2018; He et al., 2018a; Phillips et al., 2018). Total hydroxylated metabolite (i.e. the sum of free and conjugated forms) was usually measured after enzymatic de-conjugation treatment of the urine samples with sulfatase and $\beta$ glucuronidase. The free form of BCIHPP was reported to be barely detectable (Kosarac et al., 2016).

\section{Unmetabolized PEFRs}

The parent compounds have also been tested as potential urinary biomarkers of exposure to the OP triester FRs. Considering their notable presence in urine, monitoring of the unchanged TCPE and TEHP along with their corresponding diester metabolites was considered useful for better estimation of the actual exposure (Dodson et al., 2014; He et al., 2018a). With the exception of TCEP and TEHP, unchanged PEFRs were detected in lower frequencies and concentrations than their related diester metabolites, suggesting that they were less suitable biomarkers (Van den Eede et al., 2015b; He el al., 2018a). Furthermore, additive PEFRs can leach from treated rubber and plastic storage materials and possible background contamination of collected samples must therefore be considered.

\section{Chemical analysis}

Sensitive methods are being developed to improve the limits of detection and concurrently quantify a broad number of chlorinated and non-chlorinated diester and/or selected hydroxylated OP metabolites in human urine samples. Typical analytical techniques, including gas chromatographytandem mass spectrometry (GC-MS/MS) (Schindler et al. 2009a,b), high or ultra-performance liquid chromatography-tandem mass spectrometry (HPLC-MS/MS or UPLC-MS/MS), with electrospray or atmospheric pressure chemical ionization (ESI or APCI) have been used successfully in numerous biomonitoring studies (Cooper et al., 2011; Reemtsma et al., 2011; Van den Eede et al., 2013b; Su et al., 2015; Kosarac et al., 2016; Petropoulou et al., 2016; Jayatilaka et al., 2017), as has high resolution mass spectrometry (UPLC-HRMS) (Cequier et al., 2014). These same sensitive methods are also being developed for use with other non-invasive matrices such as hair, nails and human milk (Sundkvist et al., 2010; Lu et al., 2014; Kucharska et al. 2014; Liu et al., 2015; Alves et al., 2017). 


\section{Occurrence of PEFRs metabolites in human urine}

\section{General population}

Metabolites of PEFRs, essentially the diesters, were omnipresent in the urine samples collected from the general population across different countries, and there was simultaneous exposure to several PEFRs (Table 3). Reported occurrences and concentrations varied substantially between individual PEFR compounds.

BDCIPP and DPHP were the most commonly detected diester metabolites in the urine of children, mothers, and the general population, and were also the most frequently analyzed (Table 3 ). Median levels of BDCIPP and DPHP were generally in the range of $\mu \mathrm{g} / \mathrm{l}$ (about 0.1-3 $\mu \mathrm{g} / \mathrm{l}$ ), but values of hundreds of $\mu \mathrm{g} / \mathrm{l}$ were reported in urine samples of a few individuals from various geographic areas. Within each of the different studies, concentrations were highly variable between individuals and could differ by two orders of magnitude. DPHP was consistently found at high frequencies (in most cases $>90 \%$ ) in the general population in Europe, the United States and China, suggesting ubiquitous exposure to DPHP or its parent compounds (e.g., TPHP or other aryl-PEFRs such as 2-ethylhexyl diphenyl phosphate) around the world.

Highly variable detection frequencies were reported for BCIPP, BNBP, and BBOEP. In general, their median levels were around, or less than, $0.3 \mu \mathrm{g} / \mathrm{l}$.

Information on the occurrence of BCEP and isopropylphenyl phenyl phosphate (ipPP) is more limited. These were detected in more than half of the urine samples in the large majority of studies that monitored these metabolites. In most studies, their median concentrations were in the range of $0.2-2 \mu \mathrm{g} / 1$.

In almost all available studies, di-ortho-cresyl phosphate (DoCP) and/or di-para-cresyl phosphate (DpCP) (determined alone or together) were detected only occasionally, and/or at relatively low levels (i.e. median levels $<0.02 \mu \mathrm{g} / \mathrm{l}$ ) in recent studies in China and USA, suggesting limited exposure to the precursors of these metabolites in these general populations (Schindler et al., 2013; Fromme et al., 2014; Kosarac et al., 2016; Lu et al., 2017; Romano et al., 2017; Chen et al., 2018; Ospina et al., 2018). However, higher frequencies were reported in some occupationally exposed populations (Jayatilaka et al., 2017, Tao et al., 2018). DpCP was more abundant than di-meta-cresyl phosphate (DmCP) and DoCP. The synthesis and commercial compositions of TCP have in fact changed over time. Because of its neurotoxic properties, efforts have been made to minimize the amount of the ortho isomer present in commercial products containing TCP (NEG, 2009; ATSDR, 2012; US EPA, 2015).

Other PEFRs metabolites were more rarely analyzed. Tert-butyl phenyl phenyl phosphate (tbPPP) and bis(2-ethylhexyl) phosphate (BEHP) were detected infrequently (Su et al., 2015; Butt et al., 2016; Castorina et al., 2017b; Hoffman et al., 2017a; Soubri et al., 2017; Carignan et al., 2018a and b; Deziel et al., 2018; He et al., 2018a; Hoffman et al., 2018; Ingle et al., 2018; Sun et al., 2018). Dibenzyl phosphate (DBzP) was not detected in urine samples collected in the U.S.A. (Romano et al., 2017; Jayatilaka et al., 2017; Ospina et al., 2018). 


\section{Workers}

In addition to the general population, urinary biomarkers have been used to assess exposure to PEFRs in a number of workplaces (Table 4). There are some indications that internal exposure may be higher than the background exposure of the general population during several types of occupational activity. For exemple, a recent study conducted in Australia showed that urinary levels of BCIPHPP among spray polyurethane foam applicators were approximately fifty times higher than urinary levels found in the general population (Bello et al., 2018). Numerous other worker groups are expected to be more heavily exposed than the general population, especially when workers are in direct contact with large volumes of PEFRs as pure chemicals or at high concentrations in technical formulations at industrial sites and in manufacturing (e.g., at electronics dismantling facilities or electronic goods recycling areas). Measurements of PEFRs in air and dust in various occupational settings have also shown that the work environment may noticeably contribute to external exposure to PEFRs (Makinen et al., 2009; Ali et al., 2014; Wei et al., 2015; Zheng et al., 2017; Zhou et al., 2017; Muenhor et al., 2017; Bello et al., 2018; Ceballos et al., 2018; Shen et al., 2018). Nevertheless, information on the nature and extent of occupational exposures to PEFRs, especially in terms of measurements of an individual's internal exposure, is still limited and warrants further investigations (characterization, quantification, and contribution to total PEFR burden).

\section{Possible bias, limitations and strengths of the reviewed studies}

The available biomonitoring data should be analyzed in the context of several influencing factors that have already been identified in a number of studies on the evaluation of human internal exposure to PEFRs.

Concentrations of urinary PEFR metabolites varied greatly both between the populations studied and from individual to individual within cohorts (Hoffman et al., 2017a; Preston et al., 2017). Except for BDCIPP and DPHP which were typical worldwide contaminants, there was no strong common pattern for the compositional profile of urinary PEFR metabolites. This may be explained by differences in FR regulations, dietary habits, lifestyle, and use of PEFRs in household products and indoor environments (e.g., building material), between the various countries and/or study locations (Carignan et al., 2013; Butt et al., 2016; Lu et al., 2017; Chen et al., 2018; He et al., 2018b). Other factors were reported to have an impact on urinary PEFR metabolite concentrations, including timing (e.g., season of collection) (Hoffman et al., 2017a and b; Deziel et al., 2018; Ingle et al., 2018; Phillips et al., 2018), sex (e.g., women tend to have higher levels of DPHP than men, Hoffman et al., 2015b; Preston et al., 2017; He et al., 2018a; Ospina et al., 2018), behavior and activity patterns (e.g., hand washing and cleaning routines, nail painting) (Abdallah et al., 2016; Mendelsohn et al., 2016; He et al., 2018b) and age (Van den Eede et al., 2015b; Lu et al., 2017; He et al., 2018a; Ospina et al., 2018; Sun et al., 2018). Urinary concentrations of the main PEFR metabolites were generally higher in toddlers than in adults (Butt et al., 2014 and 2016; Cequier et al., 2015; Hoffman et al., 2015a; Van den Eede et al., 2015b; Chen et al., 2018; He et al., 2018a and b; Ospina et al., 2018). This is an international trend, generally attributed to the tendency of young children to crawl on the floor and to their elevated hand-to-mouth contact behavior, both of which result in increased oral and dermal contact with indoor settled dust and with products containing these chemicals (e.g., plastic toys). Differences in pharmacokinetics with age cannot be excluded.

Long-term temporal trends in the urinary levels of some PEFR metabolites have been reported among adults and/or children in the United States. Concentrations of BDCIPP in urine samples collected in 2014-2015 were 16.5 times higher than those collected in 2002-2003, while 
concentrations of DPHP increased at much lower rates until 2011 (Hoffman et al., 2017b). This may be related to changes in the use of specific PEFRs to meet the more stringent regulation of certain FRs, and improvements in the fire safety standards required for finished consumer products (e.g., furniture and textiles). For example, TCEP and TDCPP have recently been restricted or banned in children's products in several states in the USA (Vermont General Assembly, 2013; US EPA, 2015; Council of Columbia, 2016, Department of Ecology State of Washington, 2016).

In addition to the studied populations and the sources of PEFR emissions, sampling strategies may affect the study results. Human observations (Carignan et al., 2016) and in vitro and in vivo rat studies suggest that PEFRs are rapidly metabolized and eliminated in urine. PEFR half-lives in humans are generally estimated to be on the order of a few hours. The use of single spot urine samples in most studies may not represent metabolite concentration over time and may contribute to the variability in the metabolite concentrations. However, a slower urinary elimination of some metabolites (i.e. BBOEP) was recently observed in volunteers following an oral administration of TBOEP (Völkel et al., 2018). Several studies collected multiple samples over one day or the course of the study to limit within-subject variability (Meeker et al., 2013b; Hoffman et al., 2015b; Cequier et al., 2015; Su et al., 2015; Carignan et al., 2016; Hammel et al., 2016; Preston et al., 2017; He et al., 2018b; Phillips et al., 2018).

Analytical treatment of the biological samples may be critical for the measurement of PEFR urinary metabolites, e.g., conditions of urine collection and storage (Petropoulou et al., 2016; Carignan et al., 2017). Differences in the detection and quantification limits of the analytical methods employed to quantify urinary metabolites may also account for the broad range of detection rates of some metabolites within and/or across studies. Van den Eede et al. (2013b) showed that improvement of the LOQ method resulted in a higher detection frequency of BCEP and BDCIPP. In several studies, the method limit of detection (MLOD) of the hydroxylated metabolite of TCIPP, BCIPHPP, was much lower than that of the diester, BCIPP (at least ten folds - Butt et al., 2016; Hammel et al., 2016; Hoffman et al., 2017a; He et al., 2018a). BCIPHPP was in fact found at a higher incidence than BCIPP in recent biomonitoring studies that measured both metabolites in urine samples from the general population (Butt et al., 2016; Hammel et al., 2016; Hoffman et al., 2017a and 2018).

The biotransformation of PEFRs has not been extensively investigated in animals and humans and their potential metabolic pathways are principally based on qualitative in vitro analyses. In vivo, the triesters may undergo very little transformation, and/or several major metabolites other than diesters may be formed (Hou et al., 2016; Völkel et al., 2018). In addition, urine may not be the sole excretion pathway for certain PEFRs. Diester metabolites were the main metabolites targeted in urine for all PEFRs. However, there may be qualitative and quantitative metabolic differences between the compounds and/or between the metabolite kinetics. If the measured metabolite was not the best urinary biomarker of exposure, this would lead to underestimation of exposure for some PEFRs. For example, the diester metabolites of TBOEP and TCIPP were not always the main metabolites formed in vitro by human liver preparations. Several potential hydroxylated derivatives have been considered for urinary monitoring of certain PEFRs (e.g., BBOEHEP for TBOEP and BCIPHPP for TCIPP) (Van den Eede et al., 2015b; Butt et al., 2016; Hammel et al., 2016; Hoffman et al., 2017a and 2018; Bello et al., 2018; He et al., 2018a and b; Phillips et al., 2018). In fact, BBOEP and BBOEHEP were detected in $80 \%$ of urine samples from volunteers orally administered a single dose of TBOEP (20 $\mu \mathrm{g} / \mathrm{kg}$ b.w.), with comparable median values (0.16 and $0.18 \mu \mathrm{g} / \mathrm{l}$, respectively) (Völkel et al., 2018). However, the maximum concentration of BBOEHEP was much higher than that of BBOEP (3700 and $69 \mathrm{pmol} / \mathrm{kg}$ b.w., respectively) and was reached within 1-2 hours. In contrast, BBOEP showed some maxima within 25 hours, before a smooth decline. 
Several biomonitoring studies with large cohort size provide robust information on general population exposures to PEFRs. They related to a representative sample of the U.S. general population (Ospina et al., 2018), adults in China (Lu et al., 2017) and the United States (Carignan et al., 2018a and b), children in China (Chen et al., 2018) and Germany (Fromme et al., 2014), and pregnant women in the United States (Castorina et al., 2017; Hoffman et al., 2017a).

No consistent and/or uniform correlation could be established between urinary levels of some PEFR metabolites (mainly diesters) and the concentrations of the corresponding parent compounds in hand wipes or in indoor dust samples from various microenvironments (Carignan et al., 2013; Meeker et al., 2013b; Dodson et al., 2014; Fromme et al., 2014; Cequier et al., 2015; Hoffman et al., 2015b, Hammel et al., 2016; Castorina et al., 2017b; Larsson et al., 2018; Phillips et al., 2018; Tao et al., 2018; Völkel et al., 2018). Associations were generally specific to the PEFR. Some weak or positive correlations were reported, but inconstantly, for the pairs TCEP/BCEP, TDCIPP/BCIPP, TPHP/DPHP, and/or TBOEP/BBOEP. Urinary biomarkers are indicators of integrated personal exposure. Each PEFR may have several different sources and pathways of exposure, and dust sampled from specific indoor microenvironments may not be the sole and/or the primary contributor to the body burden.

\section{Occurrence of PEFRs in other human samples}

Most human biomonitoring studies have used urine as biological matrix to evaluate exposure to PEFRs. Less is known about the possibility of using PEFR levels in segments of hair and/or nails as retrospective non-invasive biomarkers for PEFR monitoring. The main PEFRs (unchanged compounds) were detected in most of the hair samples collected in various countries (e.g., TCIPP, TDCIPP, TPHP) (Table 5). Levels measured in hair were highly variable between individuals, with concentrations ranging from $\mathrm{ng} / \mathrm{g}$ to high concentrations of several $\mu \mathrm{g} / \mathrm{g}$ within the study populations (e.g., TDCIPP and TPHP, Kurcharska et al., 2015a; Liu et al., 2016). It was suggested that PEFR levels in the hair are derived from a combination of both external exposure from air and dust and internal exposure. PEFRs in hair reflect long term exposure while the occurrence of PEFR metabolites in urine most likely corresponds to recent exposure (Kurcharska et al., 2015b; Alves et al., 2017).

A number of studies have reported the presence of PEFRs in other human tissues and body fluids. PEFRs were frequently detected in placenta (Ding et al., 2016; Zhao et al., 2017) and breast milk (Sunddkvist et al., 2010; Kim et al., 2014; He et al., 2018a). The median concentration of total PEFRs was around 10-100 ng/g of lipids in breast milk from Sweden and several Asian countries, indicating that substantial exposure occurs at a young age via breastfeeding (Sunddkvist et al., 2010; Kim et al., 2014). The parent compounds (Liu et al., 2016; Zhao et al., 2016; Li et al., 2017; Ma et al., 2017; Qiao et al. 2017) and their metabolites (Bui et al., 2017) were found in human serum and blood in a few studies. The metabolism of parent PEFRs tends to occur rapidly and the measurement of metabolites concentrations in urine is generally preferred to the invasive measurement of the nonmetabolized chemicals in serum for exposure assessment.

\section{Conclusion}

This short review shows that the use of urinary levels of PEFRS metabolites for monitoring internal human exposure to these emerging pollutants is widespread and has gained increasing attention over the past few years. The biomonitoring studies confirm ubiquitous exposure of the general population to PEFRS all over the world, and potentially higher exposures in children and among a number of occupational populations. The levels and compositional patterns of urinary metabolites varied as a function of factors, such as the location and time of sampling. Further 
information on the toxicokinetics of PEFRs in humans and the continued development and validation of bioanalytical methods will allow refinement of the current biomarkers of exposure to these chemicals. Additional biomonitoring data on PEFRs are still needed in order to reduce the uncertainty in estimating human exposure, to identify the populations at risk and any possible associations with adverse health effects, to follow exposure trends, and to evaluate governmental prevention strategies and programs.

\section{Conflict of interest}

The Authors declare that they have no conflict of interest. 


\section{References}

Abdallah MAE, Pawar G, Harrad S (2016) Human dermal absorption of chlorinated organophosphate flame retardants; implications for human exposure. Toxicol Appl Pharmacol 291: 28-37

Agency for Toxic Substances and Disease Registry (ATSDR). U.S. Department of Health and Human Services. Public Health Service. (2012) Toxicological profile for phosphate ester flame retardants.

Ali N, Shahzad K, Rashid MI, Shen H, Ismail IMI, Eqani SAMAS (2017) Currently used organophosphate and brominated flame retardants in the environment of China and other developing countries (2000-2016). Environ Sci Pollut Res 24:18721-18741

Ali N, Mehdi T, Malik RN, AMAS Eqani S, Kamal A, Dirtu AC, Neels H, Covaci A (2014) Levels and profile of several classes of organic contaminants in matched indoor dust and serum samples from occupational settings of Pakista. Environ Pollut 193:269-276

Alves A, Covaci A, Voospoels S (2017) Method development for assessing the human exposure to organophosphate flame retardants in hair and nails. Chemosphere 168:692-698

Anderson J (2015) Comment on Schindler, BK; Weiss, T; Schütze, A; et al. Occupational exposure of air crews to tricresyl phosphate isomers and organophosphate flame retardants after fume events", Arch Toxicol (2013) 87:645-648. Arch Toxicol 89:259-261

Araki A, Saito I, Kanazawa A, Morimoto K, Nakayama K, Shibata E, Tanaka M, Takigawa T, Yoshimura T, Chikara H, Saijo Y, Kishi R (2014) Phosphorous flame retardants in indoor dust and their relation to asthma and allergies of inhabitants. Indoor Air 24:3-15

Arcadis EBRC (2011) Evaluation of data on flame retardants in consumer products - Final report. Contract number 17.020200/09/549040. European Commission Health and Consumer Products. https://www.ifv.nl/kennisplein/Documents/20110426-ec-arcadis-ebrc-evaluation-of-data-on-flameretardants-in-consumer-products.pdf

Ballesteros-Gomez A, Erratico CA, Van den Eele N, Ionas AC, Leonards PEG, Covaci A (2015a) In vitro metabolism of 2-ethylhexyldiphenyl phosphate (EDHPHP) by human liver microsomes. Toxicol Lett 232:203-212

Ballesteros-Gomez A, Van den Eede N, Covaci A (2015b) In vitro human metabolism of the flame retardant resorcinol bis(diphenylphosphate) (RDP). Environ Sci Technol 49:3897-3904

Bello A, Carigan CC, Xue Y, Stapleton HM, Bello D (2018) Exposure to organophosphate flame retardants in spray polyurethane foam applicators: Role of dermal exposure. Environ Int 113:55-65

Bergh C, Aberg KM, Svartengren M, Emenius G, Ostman C (2011) Organophosphate and phthalate esters in indoor air: a comparison between multi-storey buildings with high and low prevalence of sick building symptoms. J Environ Monit 13:2001-2009

Björnsdotter MK, Romera-Garcia E, Borrull J, de Boer J, Rubio S, Ballesteros-Gomez A (2018) Presence of diphenyl phosphate and aryl-phosphate flame retardants in indoor dust from different microenvironments in Spain and the Netherlands and estimation of human exposure. Environ Int 112:59-67 
Bui TT, Xu F, Van den Eede N, Cousins AP, Covaci A, Cousins IT (2017) Probing the relationship between external and internal human exposure of organophosphate flame retardants using pharmacokinetic modeling. Environ Pollut 230:550-560

Butt CM, Hoffman K, Chen A, Lorenzo A, Congleton J, Stapleton HM (2016) Regional comparison of organophosphate flame retardants (PFR) urinary metabolites and tetrabromobenzoic acid (TBBA) in mother-toddler pairs from California and New Jersey. Environ Int 94:627-634

Butt CM, Congleton J, Hoffman K, Fang M, Stapleton HM (2014) Metabolites of organophosphate flame retardants and 2-ethylhexyl tetrabromobenzoate in urine from paired mothers and toddlers. Environ Sci Technol 48:10432-10438

Canada Safety Consumer Act. Ministry of Justice. (2018) Consolidation S.C. 2010, c. 21 Current to March 26, 2018 Last amended on December 12, 2016. http://laws-lois.justice.gc.ca/PDF/C-1.68.pdf

Canbaz D, van Velzen JM, Hallner E, Zwinderman AH, Wickman M, Leonards PEG, van Ree R, van Rijt LS (2016) Exposure to organophosphate and polybrominated diphenyl ether flame retardants via indoor dust and childhood asthma. Indoor Air 26:403-413

Carignan CC, Minguez-Alarcon L, Williams PL, Meeker JD, Stapleton HM, Butt CM, Toth TL, Ford JB, Hauser R, (2018a) Paternal urinary concentrations of organophosphate flame retardant metabolites, fertility measures, and pregnancy outcomes among couples undergoing in vitro fertilization. Environ Int 111:232-238

Carignan CC, Minguez-Alarcon L, Butt CR, Williams PL, Meeker JD, Stapleton HM, Toth TL, Ford JB, Hauser R (2018b) Urinary concentrations of organophosphate flame retardant metabolites and pregnancy outcomes among women undergoing in vitro fertilization. Environ Health Perspect 125:087018-1-087018-8

Carignan CC, Butt CM, Stapleton HM, Meeker JD, Minguez-Alarcon L, Williams PL, Hauser R (2017) Influence of storage vial material on measurement of organophosphate flame retardant metabolites in urine. Chemosphere 181:440-446

Carignan CC, Fang M, Stapleton HM, Heiger-Bernays W, McClean MD, Webster TF (2016) Urinary biomarkers of flame retardant among collegiate U.S. gymnasts. Environ Int 94:362-368

Carignan CC, McClean MD, Cooper EM, Watkins DJ, Fraser AJ, Heiger-Bernays W, Stapleton HM, Webster TF (2013) Predictors of tris(1,3-dichloro-2-propyl) phosphate metabolite in the urine of office workers. Environ Int 55:56-61

Castorina R, Badman A, Stapleton HM, Butt C, Avery D, Harley KG, Gunier RB, Holland N, Eskenazi B (2017a) Current-use flame retardants: Maternal exposure and neurodevelopment in children of the CHAMACOS cohort. Chemosphere 18:574-580

Castorina R, Butt C, Stapleton HM, Avery D, Harley KG, Holland N, Eskenazi B, Bradman A (2017b) Flame retardants and their metabolites in the homes and urine of pregnant women residing in California (the CHAMACOS cohort). Chemosphere 179:159-166

Ceballos DM, Broadwater K, Page E, Croteau E, La Guardia MJ (2018) Occupational exposure to polybrominated diphenyl ether (PBDEs) and other flame retardant foam additives at gymnastics 
studios: Before, during and after the replacement of pit foam with PBDE-free foams. Environ Int $116: 1-9$

Cequier E, Sakhi AK, Marcé RM, Becher G, Thomsen C (2015) Human exposure pathways to organophosphate triesters - A biomonitoring study of mother-child pairs. Environ Int 75:159-165

Cequier E, Marce RM, Becher G, Thomsen C (2014) A high-throughput method for determination of metabolites of organophosphate flame retardants in urine by ultra performance liquid chromatographyhigh resolution mass spectrometry. Anal Chim Acta 845: 98-104

Chen Y, Fang J, ren L, Fan R, Zhang J, Liu G, Zhou L, Chen D, Yu Y, Lu S (2018) Urinary metabolites of organophosphate esters in children in South China: Concentrations, profiles and estimated daily intake. Environ Pollut 235:358-364

Cooper EM, Covaci A, van Nuijs ALN, Webster TF, Stapleton HM (2011) Analysis of flame retardant metabolites bis(1,3-dichloro-2-propyl) phosphate (BDCPP) and diphenyl phosphate ( $\mathrm{DPP}^{\circ}$ in urine using liquid chromatography-tandem mass spectrometry. Anal Bioanal Chem 401:2123-2132

Council of the District of Columbia (2016) D.C. Law 21-108. Carcinogenic Flame Retardant Prohibition Amendment Act of 2016. https://code.dccouncil.us/dc/council/laws/21-108.html

Department of Ecology, State of Washington (2016) Flame retardants concentration limits. https://ecology.wa.gov/Waste-Toxics/Reducing-toxic-chemicals/Childrens-Safe-Products-Act/Flameretardant-limits

Deziel NC, Yi H, Stapleton HM, Huang H, Zhao N, Zhang Y (2018) A case-control study of exposure to organophosphate flame retardants and risk of thyroid cancer in women. BMC Cancer 18:637

Ding J, Xu Z, Huang W, Feng L, Yang F (2016) Organophosphate ester flame retardants and plasticizers in human placenta in Eastern China. Sci Total environ 554-555: 211-217

Dirtu AC, Van den Eede N, Malarvannan G, Ionas AC, Covaci A (2012) Analytical methods for selected emerging contaminants in human matrices - A review. Anal Bioanal Chem 404:2555-2581

Dodson RE, Van den Eede N, Covaci A, Perovich LJ, Brody JG, Rudel RA (2014) Urinary biomonitoring of phosphate flame retardants: Levels in California adults and recommendations for further studies. Environ Sci Technol 48:13625-13633

Engvall K, Hult M, Corner R, Lampa E, Norbäck D, Emenius G (2010) A new multiple regression model to identify multi-family houses with a high prevalence of sick building symptoms "SBS", within the healthy sustainable house study in Stockholm (3H). Int Arch Occup Environ Health 83:8594

European Chemicals Agency (ECHA). (2018). https://echa.europa.eu

European Flame Retardants Association (EFRA) (2007) Flame retardants. http://www.bsefjapan.com/index/files/080909_3.pdf

Feng L, Ouyang F, Liu L, Wang X, Wang X, Li YJ, Murtha A, Shen H, Zhang J, Zhang JJ (2017) Levels of urinary metabolites of organophosphate flame retardants, TDCIPP, and TPHP, in pregnant women in Shangai. J Environ Public Health 2016:9416054 
Frederiksen M, Stapleton HM, Vorkamp K, Webster TF, Jensen NM, Sorensen JA, Nielsen F, Knudsen LE, Sorensen LS, Clausen PA, Nielsen JB (2018) Dermal uptake and percutaneous penetration of organophosphate esters in a human skin ex vivo model. Chemosphere, in press

Fromme H, Lahrz T, Kraft M, Fembacher L, Mach C, Dietrich S, Burkardt R, Völkel W, Göen T (2014) Organophosphate flame retardants and plasticizers in the air and dust in German daycare centers and human biomonitoring in visiting children (LUPE 3). Environ Int 71:158-163

Hammel SC, Hoffman K, Webster TF, Anderson KA, Stapleton HM (2016) Measuring personal exposure to organophosphate flame retardants using silicone wristbands and hand wipes. Environ Sci Technol 50:4483-4491

He C, Toms LML, Thai P, Van den Eede N, Wang X, Li Y, Baduel C, Harden FA, Heffernan AL, Hobson P, Cocaci A, Mueller JF (2018a) Urinary metabolites of organophosphate esters: Concentration and age trends in Australian children. Environ Int 111:124-130

He C, English K, Baduel C, Thai P, Jagals P, Ware RS, Li Y, Wang X, Sly PD, Mueller JF (2018b) Concentrations of organophosphate flame retardants and plasticizers in urine from young children in Queensland, Australia and associations with environmental factors. Environ Res 164:262-270

He C, Wang X, Thai P, Baduel C, Gallen C, Banks A, Bainton P, English K, Mueller JF (2018c) Organophosphate and brominated flame retardants in Australian indoor environments: Levels, sources, and preliminary assessment of human exposure. Environ Pollut 235:670-679

Hoffman K, Stapleton HM, Lorenzo A, Butt CM, Adair L, Herring AH, Daniels JL (2018) Prenatal exposure to organophosphates and associations with birthweight and gestational length. Environ Int $116: 248-254$

Hoffman K, Lorenzo A, Butt CM, Adair L, Herring AH, Stapleton HM, Daniels JL (2017a) Predictors of urinary flame retardant concentration among pregnant women. Environ Int 98:96-101

Hoffman K, Butt CM, Webster TF, Preston EV, Hammel SC, Makey C, Lorenzo AM, Cooper EM, Carignan C, Meeker JD, Hauser R, Soubry A, Murphy SK, Price TM, Hoyo C, Mendelson E, Congleton J, Daniels JL, Stapleton HM (2017b) Temporal trends in exposure to organophosphate flame retardants in the United States. Environ Sci Technol Lett 4:112-117

Hoffman K, Lorenzo A, Butt CM, Hammel SC, Henderson BB, Roman SA, Scheri RP, Stapleton HM, Sosa JA (2017c). Exposure to flame retardant chemicals and occurrence and severity of papillary thyroid cancer: A case-control study. Environ Int 107:235-242

Hoffman K, Butt CM, Chen A, Limkakeng AT, Stapleton HM (2015a) High exposure to organophosphate flame retardants in infants: associations with baby products. Environ Sci Technol 49:14554-14559

Hoffman K, Garantziotis S, Birnbaum LS, Stapleton HM (2015b) Monitoring indoor exposure to organophosphate flame retardants: Hand wipes and house dust. Environ Health Perspect 123: 160-165

Hoffman K, Daniels JL, Stapleton HM (2014) Urinary metabolites of organophosphate flame retardants and their variability in pregnant women. Environ Int 63:169-172

Hou R, Xu Y, Wang Z (2016) Review of OFPRs in animals and humans: Absorption, bioaccumulation, metabolism, and internal exposure research. Chemosphere 153:78-90 
Ingle ME, Minguez-Alarcon L, Carignan CC, Butt CM, Stapleton HM, Williams PL, Ford JB, Hauser R, Meeker JD (2018) The association between urinary concentrations of phosphorous-containing flame retardant metabolites and semen parameters among men from a fertility clinic. Int J Hyg Environ Health in press

Jayatilaka NK, Restrepo P, Williams LT, Ospina M, Valentin-Blasini L, Calafat AM (2017) Quantification of three chlorinated dialkyl phosphates, diphenyl phosphate, 2,3,4,5-tetrabromobenzoic acid, and four other organophosphates in human urine by solid phase extraction-high performance liquid chromatography-tandem mass spectrometry. Anal Bioanal Chem 409:1323-1332

Johnson D, Carter MD, Crow BS, Isenberg SL, Graham LA, Erol HA, Watson CM, Pantazides BG, van der Schans MJ, Langenberg JP, Noort D, Blake TA, Thomas JD, Johnson RC (2015) Quantitation of ortho-cresyl phosphate adducts to butyrylcholinesterase in human serum by immunomagneticUHPLC-MS/MS. J Mass Spectrom 50:683-692

Kanazawa A, Saito I, Araki A, Takeda M, Ma M, Saijo Y, Kishi R (2010) Association between indoor exposure to semi-volatile organic compounds and building-related symptoms among the occupants of residential dwellings. Indoor air 20:72-84

Kim JW, Isobe T, Muto M, Tue NM, Katsura K, Malarvannan G, Sudaryanto A, Chang KH, Prudente M, Viet PH, Takahashi S, Tanabe S (2014) Organophosphorus flame retardants (PFRs) in human breast milk from several Asian countries. Chemosphere 116:91-97

Kosarac I, Kubwado C, Foster WG (2016) Quantitative determination of nine urinary metabolites of organophosphate flame retardants using solid phase extraction and ultra performance liquid chromatography coupled to tandem mass spectrometry (UPLC-MS/MS)

Kucharska A, Cequier E, Thomsen C, Becher G, Covaci A, Voorspoels S (2015a) Assessment of human hair as an indicator of exposure to organophosphate flame retardants. Case study on Norwegian mother-child cohort. Environ Int 83:50-57

Kucharska A, Covaci A, Vanermen G, Voorspoels S (2015b) Non-invasive biomonitoring for PFRs and PBDEs: New insights in analysis of human hair externally exposed to selected flame retardants. Sci Total Environ 505:1062-1071

Kucharska A, Covaci A, Vanermen G, Voorspoels S (2014) Development of a broad spectrum method for measuring flame retardants - Overcoming the challenges of non-invasive human biomonitoring studies. Anal Bioanal Chem 406:6665-6675

Li P, Jin J, Wang Y, Hu J, Xu M, Sun Y, Ma Y (2017) Concentrations of organophosphorus, polybromobenzene, and polybrominated diphenyl ether flame retardants in human serum, and relationships between concentrations and donor age. Chemosphere 171:654-660.

Lipscom ST, McClelland MM, MacDonald M, Cardenas A, Anderson KA, Kile ML (2017) Crosssectional study of social behaviors in preschool children and exposure to flame retardants. Environ Health 16:23

Liu X, Yu G, Cao Z, Wang B, Huang J, Deng S, Wang Y (2017) Occurrence of organophosphorus flame retardants on skin wipes: Insight into human exposure from dermal absorption. Environ Int 98:113-119 
Liu LY, He K, Hites RA, Salamova A (2016) Hair and nails as noninvasive biomarkers of human exposure to brominated and organophosphate flame retardants. Environ Sci Technol 50:3065-3073

Liu LY, Salamova A, He K, Hites RA (2015) Analysis of polybrominated diphenyl ethers and emerging halogenated and organophosphate flame retardants in human hair and nails. J Chromatogr A 1406:251-257

Lu SY, Li YX, Zhang T, Cai D, Ruan JJ, Huang MZ, Wang L, Zhang JQ, Qiu RL (2017) Effect of Ewaste recycling on urinary metabolites of organophosphate flame retardants and plasticizers and their association with oxidative stress. Environ Sci Technol 51:2427-2437

Ma Y, Jin J, Li P, Xu M, Sun Y, Wang Y, Yuan H (2017) Organophosphate ester flame retardants concentrations and distribution in serum from inhabitants of Shandong, China, and changes between 2011 and 2015. Environ Toxicol Chem 36:414-421

Mäkinen MS, Makinen MR, Koistinen JT, Pasanen AL, Pasanen PO, Kalliokoski PJ, et al. (2009) Respiratory and dermal exposure to organophosphorous flame retardants and tetrabromobisphenol a at five work environments. Environ Sci Technol 43:941-947

Martin J, Möder M, Gaudl A, Alonso E, Reemtsma T (2015) Multi-class method for biomonitoring of hair samples using gas chromatography-mass spectrometry. Anal Bioanal Chem 407:8725-8734

Meeker JD, Cooper EM, Stapleton HM, Hauser R (2013a) Exploratory analysis of urinary metabolites of phosphorous-containing flame retardants in relation to markers of male reproductive health. Endocr Disruptors 1:e26306

Meeker JD, Cooper EM, Stapleton HM, Hauser R (2013b) Urinary metabolites of organophosphate flame retardants: Temporal variability and correlations with house dust concentrations. Environ Health Perspect 121:580-585

Meeker JD, Stapleton HM (2010) House dust concentrations of organophosphate flame retardants in relation to hormone levels and semen quality parameters. Environ Health Perspect 118:318-323

Meeker JD, Godfrey-Bailey L, Hauser R (2007) Relationships between serum hormone levels and semen quality among men from an infertility clinic. J Androl 28:397-406

Mendelsohn E, Hagopian A, Hoffman K, Butt CM, Lorenzo A, Congleton J, Webster TF, Stapleton HM (2016) Nail polish as a source of exposure to triphenyl phosphate. Environ Int 86:45-51

Ministry of Environment and Food of Denmark. Environmental Protection Agency (2016) Environmental and health screening profiles of phosphorous flame retardants. A LOUS follow-up project. Environmental project No. 1823, 2016.

Muenhor D, Moon HB, Lee S, Goosey E (2017) Organophosphorus flame retardants (PFRs) and phthalates in floor and road dust from a manual e-waste dismantling facility and adjacent communities in Thailand. J Environ Sci Health A Tox Hazard Subst Environ Eng 53: 79-90

Nordic Expert Group for Criteria Documentation of Health Risks from Chemicals (NEG) (2009) 143. Phosphate triesters with flame retardants properties. NR 2010;44(6). ISBN 978-91-85971-23-7

Office of Environmental Health Hazard (OEHHA). State of California. Assessment Safe Drinking Water and Toxic Enforcement Act of 1986. Chemicals known to the State to cause cancer or 
reproductive toxicity. December 29, 2017 https://oehha.ca.gov/media/downloads/proposition65/p65122917_0.pdf

Ospina M, Jayatilaka NK, Wong LY, Restrepo P, Calafat AM (2018) Exposure to organphosphate flame retardant chemicals in the U.S. general population: Data from the 2013-2014 National Health Nutrition Examination Survey. Environ Int 110:32-41

Petroianu GA (2016) Neuropathic organophosphates: from Scrugham, Heim and Lorot to Jake leg paralysis. Pharmazie 71:738-744

Petropoulou SS, Petreas M, Park JS (2016) Analytical methodology using ion-pair liquid chromatography-tandem mass spectrometry for the determination of four di-ester metabolites or organophosphate flame retardants in California human urine. J Chromator A 1434:70-80

Phillips AL, Hammel SC, Hoffman K, Lorenzo K, Chen AM, Webster TF, Stapleton HM (2018) Children's residential exposure to organophosphate ester flame retardants and plasticizers: Investigating exposure pathways in the TESIE study. Environ Int 116:176-185

Poma G, Sales C, Bruyland B, Christia C, Goscinny S, Van Loco J, Covaci A (2018) Occurrence of organophosphorus flame retardants and plasticizers (PFRs) in Belgian foodstuffs and estimation of dietary exposure of the adult population. Environ Sci Technool 52:2331-2338

Poma G, Glynn A, Malarvannan G, Covaci A, Darnelund PO (2017) Dietary intake of phosphorus flame retardants (PFRs) using Swedish food market basket estimations. Food Chem Toxicol 100:1-7

Preston EV, McClean MD, Henn BC, Stapleton HM, Braverman LE, Pearce EN, Makey CM, Webster TF (2017) Associations between urinary diphenyl phosphate and thyroid function. Environ Int 101:158-164

Qiao L, ZhengXB, Zheng J, Lei WX, Li HF, Wang MH, He CT, Chen SJ, Yuan JG, Luo XJ, Yu YJ, Yang ZY, Mai BX (2016) analysis of human hair to assess exposure to organophosphate flame retardants: Influence of hair segments and gender differences. Environ Res 148:177-183

Reemtsma T, Lingott J, Roegler S (2011) Determination of 14 monoalkyl phosphates, dialkyl phosphates and dialkyl thiophosphates by LC-MS/MS in human urinary samples. Sci Total Environ 409:1990-1993.

Romano ME, Hawley NL, Eliot M, Calafat AM, Jayatilaka NK, Kelsey K, McGarvey S, Phipps MG, Savitz DA, Werner EF, Braun JM (2017) Variability and predictors of urinary concentrations of organophosphate flame retardant metabolites among pregnant women in Rhode Island. Environ Health $16: 40$

Shen B, Whitehead TP, Gill R, Dhaliwal J, Brown FR, Petreas M, PattonS, Hammond SK (2018) Organophosphate flame retardants in dust collected from United States fire stations. Environ Int 112:41-48

Schindler BK, Koslitz S, Weiss T, Broding HC, Brüning T, Bünger J (2014) Exposure of aircraft maintenance technicians to organophosphates from hydraulic fluids and turbine oils: A pilot study. Int J Hyg Environ Health 217:34-37 
Schindler BK, Weiss T, Schütze A, Koslitz S, Broding HC, Bünger J, Brüning T (2013) Occupational exposure of air crews to tricresyl phosphate isomers and organophosphate flame retardants after fume events. Arch Toxicol 87:645-648

Schindler BK, Förster K, Angerer J (2009a) Determination of human urinary organophosphate flame retardant metabolites by solid-phase extraction and gas chromatography-tandem mass spectrometry. $\mathrm{J}$ Chromatogr B 877:375-381

Schindler BK, Förster K, Angerer J (2009b) Quantification of two urinary metabolites of organophosphorus flame retardants by solid-phase extraction and gas chromatography-tandem mass spectrometry. Arch Toxicol 395:1167-1171

Schopfer LM, Masson P, Lamourette P, Simon S, Lockridge O (2014) Detection of cresyl phosphatemodified butyrylcholinesterase in human plasma for chemical exposure associated with aerotoxic syndrome. Anal Biochem 461:17-26

Schreder ED, Uding N, La Guardia MJ (2016) Inhalation a significant exposure route for chlorinated organophosphate flame retardants. Chemosphere 150:499-504

Shen B, Whitehead TP, Gill R, Dhaliwal J, Brown FR, Petreas M, Patton S, Hammond SK (2018) Organophosphate flame retardants in dust collected from United States fire stations. Environ Int $112: 41-48$

Soubry A, Hoyo C, Butt CM, Fieuws S, Price TM, Murphy SK, Stapleton HM (2017) Human exposure to flame-retardants is associated with aberrant DNA methylation at imprinted genes in sperm. Environ Epigenet 3:dvx003

Su G, Lechter RJ, Yu H, Gooden DM, Stapelton HM (2016) Determination of glucuronide conjugates of hydroxyl triphenyl phosphate (OH-TPHP) metabolites in human urine and its use as a biomarker of TPHP exposure. Chemosphere 149:314-319

Su G, Letcher RJ, Yu H (2015) Determination of organophosphate diesters in urine samples by a highsensitivity method based on ultra high pressure liquid chromatography-triple quadupole-mass spectrometry. J Chromatogr A 1426:154-160

Sun Y, Gong X, Lin W, Wang Y, Wu M, Kannan K, Ma J (2018) Metabolites of organophosphate ester flame retardants in urine from Shanghai, China. Environ Res 164:507-515

Sundkvist AM, Olofsson U, Haglund P (2010) Organophosphorus flame retardants and plasticizers in marine and fresh water biota and in human milk. J Environ Monit 12:943-951

Tacal O, Schopfer LM (2014) Healthy F-16 pilots show no evidence of exposure to tri-ortho-cresyl phosphate trough the on-board oxygen generating system. Chem Biol Interact 215:69-74

Tao Y, Shang Y, Li J, Feng J, He Z, Covaci A, Wang P, Luo J, Mao X, Shi B, Hu L, Luo D, Mei S (2018) Exposure to organophosphate flame retardants of hotel room attendants in Wuhan City, China. Environ Pollut 236:626-633

Thomas MB, Stapleton HM, Dills RL, Violette HD, Christakis DA, Sathyanarayana S (2017) Demographic and dietary risk factors in relation to urinary metabolites of organophosphate flame retardants in toddlers. Chemosphere 185: 918-925 
U.S. Environmental Protection Agency (US EPA) (2015) Flame retardants used in flexible polyurethane foams: an alternatives assessment update.

https://www.epa.gov/sites/production/files/2015-08/documents/ffr final.pdf

U.S. Environmental Protection Agency (US EPA) (2017) Regional Screening Level (RSL) Summary Table (TR=1E-06, HQ=0.1) November 2017. https://semspub.epa.gov/work/HQ/197027.pdf

Van den Eede N, Tomy G, Tao F, Halldorson T, Harrad S, Neels H, Covaci A (2016a) Kinetics of tris (1-chloro-2-propyl) phosphate (TCIPP) metabolism in human liver microsomes and serum.

Chemosphere 144:1299-1305

Van den Eede N, Ballesteros-Gomez A, Neels H, Covaci A (2016b) Does biotransformation of aryl phosphate flame retardants in blood cast a new perspective on their debated biomarkers. Environ Sci Technol 50:12439-12445

Van den Eede N, De Meester I, Maho W, Neels H, Covaci A (2016c) Biotransformation of three flame retardants and plasticizers in primary human hepatocytes: untargeted metabolite screening and quantitative assessment. J Appl Toxicol 36:1401-1408

Van den Eede N, Erratico C, Exarchou V, Maho W, Neels H, Covaci A (2015a) In vitro biotransformation of tris(2-butoxyethyl) phosphate (TBOEP) in human liver and serum. Toxicol Appl Pharmacol 284:246-253

Van den Eede N, Hefferman AL, Aylward LL, Hobson P, Neels H, Mueller JF, Covaci A (2015b) Age as a determinant of phosphate flame retardant exposure of the Australian population and identification of novel urinary PFR metabolites. Environ Int 74:1-8

Van den Eede N, Maho W, Erratico C, Neels H, Covaci A (2013a) First insights in the metabolism of phosphate flame retardants and plasticizers using human liver fractions. Toxicol Lett 223:9-15

Van den Eede N, Neels H, Jorens PG, Covaci A (2013b) Analysis of organophosphate flame retardant diester metabolites in human urine by liquid chromatography electrospray ionization tandem mass spectrometry. J Chromator A 1303: 48-53

Van der Veen I, de Boer J (2012) Phosphorous flame retardants: Properties, production, environmental occurrence, toxicity and analysis. Chemosphere 88:1119-1153

Vermont General Assembly (2013) The Vermont Statutes Online. Title 9: Commerce And Trade. Chapter 80: Flame Retardants. § 2971. Repealed. 2013, No. 85, § 1 to $§ 2980$. Department of Health rulemaking; TCPP. https://legislature.vermont.gov/statutes/fullchapter/09/080

Völkel W, Fuchs V, Wöckner M, Fromme H (2018) Toxicokinetic of tris(2-butoxyethyl) phosphate (TBOEP) in humans following single oral administration. Arch Toxicol 92:651-660

Wei GL, LI DQ, Zhuo MN, Liao YS, Xie ZY, Guo TL, Li JJ, Zhang SY, Liang ZQ (2015)

Organophosphorus flame retardants and plasticizers: Sources, occurrence, toxicity and human exposure. Environ Pollut 196:29-46

WeissT, Schindler BK, Schütze A, Koslitz S, Broding HC, Bünger J, Brüning T (2015) Reply to the letter of Anderson J entitled "Comment on Schindler, BK; Weiss, T; Schütze, A; et al. Occupational 
exposure of air crews to tricresyl phosphate isomers and organophosphate flame retardants after fume events. Arch Toxicol (2013) 87:645-648". Arch Toxicol 89:263-264

Wu M, Yu G, Cao Z, Wu D, Liu K, Deng S, Huang J, Wang B, Wang Y (2016) Characterization and human exposure assessment of organophosphate flame retardants in indoor dust from several microenvironments of Beijing, China. Chemosphere 150:465-471

Xu F, Tay JH, Covaci A, Padilla-Sanchez JA, Papadopoulou E, Smastuen L, Neels H, Sellström U, de Wit CA (2017) Assessment of dietary exposure to organohalogen contaminants, legacy and emerging flame retardants in a Norwegian cohort. Environ Int 102:236-243

Xu F, Giovanoulis G, van Waes S, Padilla-Sanchez JA, Papadopoulou E, Magner J, Haug LS, Neels $\mathrm{H}$, Covaci A (2016) Comprehensive study of human external exposure to organophosphate flame retardants via air, dust, and hand wipes: the importance of sampling and assessment strategy. Environ Sci Technol 50:7752-7760

Yan X, Zheng X, Wang M, Zheng J, Xu R; Zhuang X, Lin Y, Ren M (2018) Urinary metabolites of phosphate flame retardants in workers occupied with e-waste recycling and incineration. DOI: 10.1016/j.chemosphere 2018.02.148

Yoshida T, Yoshida J (2012) Simultaneous analytical method for urinary metabolites of organophosphorus compounds and moth repellents in general population. J Chromatogr B 880: 66-73

Zhao F, Chen M, Gao F, Shen H, Hu J (2017) Organophosphorus flame retardants in pregnant women and their transfer to chorionic villi. Environ Sci Technol 51:6489-6497

Zhao F, Wan Y, Zhao H, Hu W, Mu D, Webster TF, Hu J (2016) Levels of blood organophosphorus flame retardants an association with changes in human sphingolipid homeostasis. Environ Sci Technol 50:8896-8903

Zhang X, Zou W, Mu L, Chen Y, Ren C, Hu X, Zhou Q (2016) Rice ingestion is a major pathway for human exposure to organophosphate flame retardants (OPFRs) in China. J Hazard Mater 318:686-693

Zheng X, Qiao L, Covaci A, Sun R, Guo H, Zheng J, Luo X, Xie Q, Mai B (2017) Brominated and phosphate flame retardants (FRs) in indoor dust from different microenvironments: Implications for human exposure via dust ingestion and dermal contact. Chemosphere 184:185-191

Zheng X, Xu F, Luo X, Mai B, Covaci A (2016) Phosphate flame retardants and novel brominated flame retardants in home-produced eggs from e-waste recycling region in China. Chemosphere 150:545-550

Zhou L, Hiltscher M, Püttmann W (2017) Occurrence and human exposure assessment of organophosphate flame retardants in indoor dust from various microenvironments of Rhine/Main region, Germany. Indoor Air 27:1113-1127 
Table 1. A summary of recent epidemiological studies on the potential health effects of PEFRs

\begin{tabular}{|c|c|c|c|c|}
\hline Author, location & Subjects and study period & Sampling & Exposure assessment $^{\mathrm{a}}$ & Health effects related to PEFRs exposure \\
\hline \multicolumn{5}{|c|}{ Hormonal and reproductive effects } \\
\hline $\begin{array}{l}\text { Carignan et al., 2018a } \\
\text { USA }\end{array}$ & $\begin{array}{l}201 \text { couples from the } \\
\text { Environment and } \\
\text { Reproductive Health } \\
\text { (EARTH) prospective cohort } \\
\text { study }^{\text {a }} \\
2005-2015\end{array}$ & $\begin{array}{l}\text { One or two spot urine } \\
\text { samples per in vitro } \\
\text { fertilization cycle }\end{array}$ & $\begin{array}{l}\text { Urinary metabolites in } \\
\text { males: BCIP, BDCIPP, } \\
\text { DPHP, ip-PPP, tert } \\
\text { butyl-phenylphenyl } \\
\text { phosphate (tb-PPP) }\end{array}$ & $\begin{array}{l}\text { Paternal exposure and partner's pregnancy outcome } \\
\text { Association between paternal preconception BDCIPP levels and } \\
\text { reduced probability of oocyte fertilization. } \\
\text { No association between PFR metabolites and the proportion of } \\
\text { cycles resulting in implantation, clinical pregnancy and live birth. }\end{array}$ \\
\hline $\begin{array}{l}\text { Carignan et al., 2018b } \\
\text { USA }\end{array}$ & $\begin{array}{l}211 \text { women from the } \\
\text { Environment and } \\
\text { Reproductive Health } \\
\text { (EARTH) prospective cohort } \\
\text { study }{ }^{\text {a }} \\
2005-2015\end{array}$ & $\begin{array}{l}\text { One or two spot urine } \\
\text { samples per in vitro } \\
\text { fertilization cycle }\end{array}$ & $\begin{array}{l}\text { Urinary metabolites in } \\
\text { females: BCIP, } \\
\text { BDCIPP, DPHP, ip- } \\
\text { PPP, tb-PPP }\end{array}$ & $\begin{array}{l}\text { Maternal exposure and pregnancy outcome } \\
\text { Association between the levels of two individual metabolites (i.e. } \\
\text { DPHP and tb-PPP) and of total metabolites, and reduced } \\
\text { probability of successful fertilization, implantation, clinical } \\
\text { pregnancy, and live birth. }\end{array}$ \\
\hline $\begin{array}{l}\text { Ingle et al., } 2018 \\
\text { USA }\end{array}$ & $\begin{array}{l}220 \text { men from the } \\
\text { Environment and } \\
\text { Reproductive Health } \\
\text { (EARTH) cohort study a } \\
2005-2015\end{array}$ & $\begin{array}{l}\text { One to five urine and } \\
\text { sperm samples }\end{array}$ & $\begin{array}{l}\text { Urinary metabolites in } \\
\text { males: BCIP, BDCIPP, } \\
\text { DPHP, ip-PPP, tb-PPP }\end{array}$ & $\begin{array}{l}\text { Exposure in men and semen parameters } \\
\text { No consistent association between individual metabolites and } \\
\text { semen parameters. }\end{array}$ \\
\hline $\begin{array}{l}\text { Preston et al., } 2017 \\
\text { USA }\end{array}$ & $\begin{array}{l}26 \text { men and } 25 \text { women } \\
\text { as a part of the Flame } \\
\text { Retardant Exposure Study } \\
\text { (FlaRE) } \\
2010-2011\end{array}$ & $\begin{array}{l}\text { Spot urine and blood } \\
\text { samples at } 1,6 \text { and } 12 \\
\text { months }\end{array}$ & Urinary DPHP & $\begin{array}{l}\text { Adult exposure to TPHP and circulating thyroid hormones } \\
\text { No association between DPHP levels and thyroxine (free T4), } \\
\text { triiodothyroxine (free and total T3) or thyroid stimulating hormone } \\
\text { (TSH) concentrations in serum. } \\
\text { Association between DPHP levels and increased total T4, } \\
\text { especially in women. }\end{array}$ \\
\hline $\begin{array}{l}\text { Soubry et al., } 2017 \\
\text { USA }\end{array}$ & $\begin{array}{l}67 \text { men as a part of the } \\
\text { Gametic Epigenetic } \\
\text { Reprogramming (TIEGER) } \\
\text { cross-sectional study } \\
2012-2013\end{array}$ & $\begin{array}{l}\text { Spot urine and sperm } \\
\text { samples on the same day }\end{array}$ & $\begin{array}{l}\text { Urinary metabolites: } \\
\text { BCIP, BDCIPP, DPHP, } \\
\text { ip-PPP, tb-PPP }\end{array}$ & $\begin{array}{l}\text { Exposure in men and DNA methylation at imprinted genes in sperm } \\
\text { Association between PEFRs metabolites (i.e.BDCIPP, DPHP, ip- } \\
\text { PPP) and small methylation differences (hyper- or hypo- } \\
\text { methylation of different genes specific to the metabolites). }\end{array}$ \\
\hline $\begin{array}{l}\text { Meeker et al., 2013a } \\
\text { USA }\end{array}$ & $\begin{array}{l}33 \text { men from couples who } \\
\text { were infertile due to a male } \\
\text { factor, a female factor, or } \\
\text { both }\end{array}$ & $\begin{array}{l}\text { One urine, blood, and } \\
\text { semen sample }\end{array}$ & $\begin{array}{l}\text { Urinary BDCIPP and } \\
\text { DPHP }\end{array}$ & $\begin{array}{l}\text { Exposure in men, and semen parameter, and reproductive and } \\
\text { thyroid hormones } \\
\text { Association between BDCIPP levels and decreases in sperm quality } \\
\text { parameters, and concentrations of total T3 and FSH in serum. }\end{array}$ \\
\hline
\end{tabular}




\begin{tabular}{|c|c|c|c|c|}
\hline & $\begin{array}{l}\text { (Subset of a parent study: } \\
\text { Meeker et al., 2007) } \\
\text { 2003-2004 }\end{array}$ & & & $\begin{array}{l}\text { Association between DPHP levels and decreased sperm } \\
\text { concentration (no significant changes in hormones, e.g., prolactin). }\end{array}$ \\
\hline $\begin{array}{l}\text { Meeker et al., } 2010 \\
\text { (Meeker et al., 2007) } \\
\text { USA }\end{array}$ & $\begin{array}{l}50 \text { men from couples who } \\
\text { were infertile due to a male } \\
\text { factor, a female factor, or } \\
\text { both } \\
\text { (Subset of a parent study: } \\
\text { Meeker et al., 2007) }\end{array}$ & $\begin{array}{l}\text { Dust collected at the } \\
\text { homes of men who } \\
\text { participated in the parent } \\
\text { study in } 2002-2007 . \\
\text { One blood and semen } \\
\text { sample ( } 38 \text { samples for } \\
\text { semen) }\end{array}$ & $\begin{array}{l}\text { TDCPP and TPHP in } \\
\text { dust }\end{array}$ & $\begin{array}{l}\text { Exposure in men and semen parameters and reproductive and } \\
\text { thyroid hormones } \\
\text { Association between TDCPP levels and changes in serum } \\
\text { concentrations of hormones (decrease in free T4 and increase in } \\
\text { prolactin). } \\
\text { Association between TPHP and increased prolactin and decreased } \\
\text { sperm concentration. }\end{array}$ \\
\hline \multicolumn{5}{|c|}{ Effects at birth and in childhood } \\
\hline $\begin{array}{l}\text { Hoffman et al., } 2018 \\
\text { USA }\end{array}$ & $\begin{array}{l}349 \text { mothers and their child } \\
\text { from the cohort of the } \\
\text { Pregnancy Infection and } \\
\text { Nutrition study (PIN) } \\
2002-2005\end{array}$ & $\begin{array}{l}\text { Single spot urine samples } \\
\text { from the mothers during } \\
\text { late-second or early-third } \\
\text { trimester ( } 24-30 \text { weeks } \\
\text { of pregnancy) }\end{array}$ & $\begin{array}{l}\text { Urinary metabolites: } \\
\text { BCIP, BDCIPP, DPHP, } \\
\text { ip-PPP, tb-PPP, 1- } \\
\text { hydroxy-2-propyl } \\
\text { phosphate (BCIPH- } \\
\text { IPP) }\end{array}$ & $\begin{array}{l}\text { Maternal exposure and birth outcomes } \\
\text { Higher levels of BDCIPP and ip-PPP associated with decreased } \\
\text { gestational duration and increased preterm births ( }<37 \text { weeks } \\
\text { gestation) among female infants. }\end{array}$ \\
\hline $\begin{array}{l}\text { Castorina et al., 2017a, } \\
\text { USA }\end{array}$ & $\begin{array}{l}310 \text { mothers and their } 7- \\
\text { year-old children from a } \\
\text { longitudinal birth cohort } \\
\text { study (Center for the Health } \\
\text { Assessment of Mothers and } \\
\text { Children of Salinas- } \\
\text { CHAMACOS) } \\
1999-2000\end{array}$ & $\begin{array}{l}\text { Single spot urine samples } \\
\text { from the mothers at } 26 \\
\text { weeks of pregnancy }\end{array}$ & $\begin{array}{l}\text { Urinary metabolites: } \\
\text { BCIP, BDCIPP, DPHP, } \\
\text { ip-PPP, tb-PP } \\
\text { (Castorina et al., } \\
\text { 2017b) }\end{array}$ & $\begin{array}{l}\text { In utero exposure and neurodevelopmental outcome } \\
\text { (associations analyzed: total PEFR metabolites, TDCIPP, TPHP, } \\
\text { ip-PPP) } \\
\text { Association between DPHP and total PEFR metabolites levels, and } \\
\text { decreased cognitive function (full scale IQ and working memory). } \\
\text { No association between prenatal BDCIPP and ip-PPP levels and } \\
\text { neurobehavioral development. }\end{array}$ \\
\hline $\begin{array}{l}\text { Lipscom et al., } 2017 \\
\text { USA }\end{array}$ & $\begin{array}{l}72 \text { children (aged 3-5 years) } \\
2012-2013\end{array}$ & $\begin{array}{l}\text { Passive wristband } \\
\text { samplers worn } \\
\text { continuously for } 7 \text { days }\end{array}$ & $\begin{array}{l}\text { FRs in wristbands, } \\
\text { including brominated } \\
\text { diphenyl ethers (BDEs) } \\
\text { and total PEFRs }\end{array}$ & $\begin{array}{l}\text { Child exposure and social behavior } \\
\text { Cross-sectional association between total PEFRs levels and poorer } \\
\text { social skills in a few domains (e.g., externalizing behavior). }\end{array}$ \\
\hline \multicolumn{5}{|c|}{ Respiratory outcomes and immunotoxicity } \\
\hline $\begin{array}{l}\text { Sun et al., } 2018 \\
\text { China }\end{array}$ & $\begin{array}{l}180 \text { participants ( } 130 \text { adults, } \\
27 \text { students, and } 33 \text { children) } \\
2016-2017\end{array}$ & Single spot urine sample & $\begin{array}{l}9 \text { urinary metabolites } \\
\text { including BCEP, } \\
\text { BCIPP, BDCIPP, } \\
\text { DNBP, DPHP, } \\
\text { BBOEP, BEHP }\end{array}$ & $\begin{array}{l}\text { Indoor exposure and allergy } \\
\text { Association between DNBP levels and self-reported symptoms of } \\
\text { allergy. }\end{array}$ \\
\hline Canbaz et al., 2016 & 110 children who developed & Dust collected from the & PBDEs and PEFRs in & FRs in mother's mattress dust and the development of childhood \\
\hline
\end{tabular}




\begin{tabular}{|c|c|c|c|c|}
\hline Sweeden & $\begin{array}{l}\text { asthma at } 4 \text { or at } 8 \text { years, } \\
\text { matched with } 110 \text { controls } \\
\text { from a large prospective } \\
\text { study } \\
1994-1996\end{array}$ & $\begin{array}{l}\text { mother's mattress two } \\
\text { months after child birth f }\end{array}$ & $\begin{array}{l}\text { dust, including TECP, } \\
\text { TCIP, TDCIPP, TPHP, } \\
\text { TBOEP, EHDPHP, } \\
\text { mmp-TCP }\end{array}$ & $\begin{array}{l}\text { asthma } \\
\text { No association between higher concentrations of PEFRs and the } \\
\text { development of childhood asthma. }\end{array}$ \\
\hline $\begin{array}{l}\text { Araki et al., } 2014 \\
\text { Japan }\end{array}$ & $\begin{array}{l}516 \text { inhabitants (adults and } \\
\text { children) in } 156 \text { different } \\
\text { homes } \\
\text { Cross-sectional study. } \\
2004-2006\end{array}$ & $\begin{array}{l}\text { Indoor floor and multi- } \\
\text { surface dust collected in } \\
\text { each family's home in } \\
2004,2005 \text {, and } 2006\end{array}$ & $\begin{array}{l}11 \text { PEFRS such as } \\
\text { TBOEP, TCIPP, } \\
\text { TDCIPP, TPHP (most } \\
\text { frequently detected) in } \\
\text { dust }\end{array}$ & $\begin{array}{l}\text { Indoor exposure and asthma and allergy } \\
\text { Association between TNBP levels and an inhabitant's medical } \\
\text { treatment for asthma and allergic rhinitis. } \\
\text { Association between TCIPP and TDCIPP levels and recent medical } \\
\text { treatment of an inhabitant for atopic dermatitis. }\end{array}$ \\
\hline $\begin{array}{l}\text { Bergh et al., } 2011 \\
\text { Sweden }\end{array}$ & $\begin{array}{l}\text { Adults (men and women). } \\
\text { Part of a larger study, the } \\
\text { Healthy Sustainable Houses } \\
\text { study in Stockholm }(3 \mathrm{H}) \text {. } \\
\text { Frequency of SHS studied in } \\
481 \text { multi-family buildings } \\
\text { with } 10506 \text { dwellings } \\
\text { (Engvall et al., 2010). } \\
2006\end{array}$ & $\begin{array}{l}\text { Indoor air from } 169 \\
\text { apartments in buildings } \\
\text { with a high incidence of } \\
\text { reported SHS (2-4 } \\
\text { apartment/building) }\end{array}$ & $\begin{array}{l}\text { Phthalates and } 15 \\
\text { organophosphorous } \\
\text { flame retardants }\end{array}$ & $\begin{array}{l}\text { Indoor exposure and sick house syndrome (SHS) (i.e. irritation of } \\
\text { the eyes, nose, throat, skin and coughing) } \\
\text { No association between PEFR levels and reported SHS symptoms, } \\
\text { compared to buildings with low prevalence of SHS. }\end{array}$ \\
\hline $\begin{array}{l}\text { Kanazawa et al., } 2010 \\
\text { Japan }\end{array}$ & $\begin{array}{l}134 \text { inhabitants ( } 64 \text { men and } \\
70 \text { women) of } 41 \text { dwellings } \\
\text { Cross-sectional study } \\
2006-2007\end{array}$ & $\begin{array}{l}\text { Indoor air and dust } \\
\text { (surface, floor) from the } \\
\text { dwelling }\end{array}$ & $\begin{array}{l}\text { Semi-volatile organic } \\
\text { compounds including } \\
11 \text { PEFRs }\end{array}$ & $\begin{array}{l}\text { Indoor exposure and sick house syndrome (SHS) } \\
\text { Association between TBNP levels (floor dust) and reported } \\
\text { mucosal symptoms of SHS. } \\
\text { Inverse association between TBEP concentrations (floor dust) and } \\
\text { reported mucosal symptoms of SHS. }\end{array}$ \\
\hline \multicolumn{5}{|l|}{ Others } \\
\hline $\begin{array}{l}\text { Deziel et al., } 2018 \\
\text { USA }\end{array}$ & $\begin{array}{l}100 \text { cases and } 100 \text { controls } \\
\text { Cases: Patients newly } \\
\text { diagnosed with papillary } \\
\text { thyroid cancer (PTC) } \\
\text { (women) } \\
2010-2013\end{array}$ & Single spot urine samples & $\begin{array}{l}6 \text { urinary metabolites: } \\
\text { BCIPP, BCIHPP, } \\
\text { BDCIPP, ip-PPP, } \\
\text { DPHP and tert-butyl } \\
\text { phenyl phenyl } \\
\text { phosphate (tb-PPP) }\end{array}$ & $\begin{array}{l}\text { Adult exposure and PTC } \\
\text { No association between urinary PEFR metabolites concentrations } \\
\text { measured at the time of diagnosis and risk of PTC. } \\
\text { Tb-PPP was only detected in } 6 \% \text { of samples and was therefore } \\
\text { excluded for analysis. }\end{array}$ \\
\hline $\begin{array}{l}\text { Hoffman et al., 2017c } \\
\text { USA }\end{array}$ & $\begin{array}{l}70 \text { cases and } 70 \text { controls } \\
\text { Cases: Patients newly } \\
\text { diagnosed with papillary } \\
\text { thyroid cancer (PTC) (men } \\
\text { and women) }\end{array}$ & $\begin{array}{l}\text { Dust collected at each } \\
\text { participant's home }\end{array}$ & $\begin{array}{l}\text { FRs in household dust, } \\
\text { including BDEs, } \\
\text { TCEP, TCIPP, } \\
\text { TDCIPP and TPHP }\end{array}$ & $\begin{array}{l}\text { Adult exposure and PTC } \\
\text { Higher levels of TCEP associated with increased odds of PTC, } \\
\text { especially larger and more aggressive tumors. }\end{array}$ \\
\hline
\end{tabular}




\begin{tabular}{|c|c|c|c|c|}
\hline & $2014-2016$ & & & \\
\hline $\begin{array}{l}\text { Lu et al., } 2017 \\
\text { China }\end{array}$ & $\begin{array}{l}221 \text { adults and children } \\
2014\end{array}$ & Single spot urine samples & 8 urinary metabolites: & $\begin{array}{l}\text { Adult exposure and oxidative stress (8-OHdG in urine) } \\
\text { Association between PEFR metabolite levels (i.e. DCEP, DNBP, } \\
\text { DPHP) and a higher concentration of } 8-\mathrm{OHdG} \text {, in e-waste } \\
\text { dismantling sites. }\end{array}$ \\
\hline $\begin{array}{l}\text { Zhao et al., } 2016 \\
\text { China }\end{array}$ & $\begin{array}{l}154 \text { men and } 101 \text { women } \\
2012\end{array}$ & One blood sample & $\begin{array}{l}\text { TCIPP, TBOEP, } \\
\text { TPHP, TEP, TNBP, } \\
\text { EHDPP in blood }\end{array}$ & $\begin{array}{l}\text { Adult exposure and changes in sphingolipid homeostasis } \\
\text { Association between levels of the six PEFRs and increased } \\
\text { sphingomyelin concentration. } \\
\text { Negative association between EHDPP, TPHP, and TNBP levels } \\
\text { and sphingosine 1-phosphate concentration. }\end{array}$ \\
\hline
\end{tabular}

${ }^{\text {a }}$ Participants originated from couples whose infertility diagnosis was either male factor, female factor, or a combination of both. 
Table 2 Parent compounds and metabolites

\begin{tabular}{|c|c|c|c|}
\hline \multicolumn{2}{|l|}{ Parent PEFR } & \multicolumn{2}{|l|}{ PEFR metabolite } \\
\hline Full name (CAS number) & Abbreviation & Full name & Abbreviation \\
\hline \multicolumn{4}{|l|}{$\begin{array}{l}\text { Halogenated organophosphorous } \\
\text { compounds }\end{array}$} \\
\hline $\begin{array}{l}\text { Tris(2-chloroethyl) phosphate } \\
(115-96-8)\end{array}$ & TCEP & Bis(2-chloroethyl) phosphate & BCEP \\
\hline \multirow[t]{2}{*}{$\begin{array}{l}\text { Tris(1-chloro-2-propyl) phosphate } \\
\text { (13674-84-5) }\end{array}$} & TCIPP & Bis(1-chloro-2-propyl) phosphate & BCIPP \\
\hline & & $\begin{array}{l}\text { Bis(1-chloro-2-propyl) } 1 \text { - } \\
\text { hydroxy-2-propyl phosphate }\end{array}$ & BCIPHPP \\
\hline $\begin{array}{l}\text { Tris(1,3-dichloro-2-propyl) phosphate } \\
\text { (or isopropyl) (13674-87-8) }\end{array}$ & TDCIPP & $\begin{array}{l}\text { Bis(1,3-dichloro-2-propyl) } \\
\text { phosphate }\end{array}$ & BDCIPP \\
\hline \multicolumn{4}{|l|}{$\begin{array}{l}\text { Non-halogenated organophosphorous } \\
\text { compounds }\end{array}$} \\
\hline Tri-n-butyl phosphate (126-73-8) & TNBP & Di-n-butyl phosphate & DNBP \\
\hline Tris(2-ethylhexyl) phosphate (78-42-2) & TEHP & Bis(2-ethylhexyl) phosphate & BEHP \\
\hline $\begin{array}{l}\text { Mono-substituted isopropyl triphenyl } \\
\text { phosphate (Isopropylphenyl diphenyl } \\
\text { phosphate) } \\
\text { (several isomers : } 55864-04-5,69515- \\
46-4,64532-94-1 \text { ) }\end{array}$ & Mono-ITP & Isopropylphenyl phenyl phosphate & ip-PPP \\
\hline Tris(2-butoxyethyl) phosphate $(78-51-3)$ & TBOEP & Bis(2-butoxyethyl) phosphate & BBOEP \\
\hline & & $\begin{array}{l}\text { Bis(2-butoxyethyl)-(2- } \\
\text { hydroxyethyl) phosphate }\end{array}$ & BBOEHEP \\
\hline Triphenyl phosphate (115-86-6) & TPHP & Diphenyl phosphate & DPHP \\
\hline Tricresyl phosphate (1330-78-5) & TCP & Dicresyl phosphate & $\mathrm{DCP}$ \\
\hline $\begin{array}{l}\text { Ortho, meta, and para isomers }(78-30-8, \\
563-04-2,78-32-0, \text { respectively) }\end{array}$ & $\begin{array}{l}\text { ToCP, TmCP, } \\
\text { TpCP }\end{array}$ & & \\
\hline $\begin{array}{l}\text { 2-ethylhexyl diphenyl phosphate } \\
(1241-94-7)\end{array}$ & EHDPP & $\begin{array}{l}\text { 5-hydroxy-2-ethylhexyl diphenyl } \\
\text { phosphate }\end{array}$ & $\begin{array}{l}5-\mathrm{OH}- \\
\text { EHDPHP }\end{array}$ \\
\hline
\end{tabular}

Chemical structures of PEFR metabolites are given in Supplementary material S1

The commercial mixtures TCP, TCIPP, and triisopropylated phenyl phosphate contain varying amounts of their isomers, e.g., the most abundant isomer in commercial products of TCIPP is generally the completely branched isomer, CAS: $13674-84-5$. 
Table 3. Urinary concentrations of the principal metabolites of PEFRs in general populations $(\mu \mathrm{g} / \mathrm{l})$.

$50^{\text {th }}$ percentile $(\max ) \% \geq$ limit of detection (LOD)

\begin{tabular}{|c|c|c|c|c|c|c|c|c|c|c|}
\hline Author, location & $\begin{array}{l}\text { Sampli } \\
\text { ng year }\end{array}$ & $\mathrm{N}$ (population) & BCEP & BCIPP & BCIPHPP & BDCIPP & DNBP & ip-PPP & BBOEP & DPHP \\
\hline \multicolumn{11}{|l|}{ Australia } \\
\hline He et al., 2018a & $\begin{array}{l}2014- \\
2015\end{array}$ & $\begin{array}{l}\text { Children (0-5 years) } \\
\text { Pooled urine samples } \\
\text { ( } 20 \text { children/pool, } 20 \text { pools }) \\
\text { Not adjusted for specific gravity }\end{array}$ & $\begin{array}{l}<0.01^{\mathrm{a}}(0.036) \\
\quad \mathbf{1 5}\end{array}$ & $0.85^{\mathrm{a}}(3.2) \mathbf{1 0 0}$ & $0.43^{\mathrm{a}} .(2.1) 100$ & $2.6^{\mathrm{a}}(19) 100$ & $0.18^{\mathrm{a}}(0.55) \mathbf{1 0 0}$ & - & $0.32^{\mathrm{a}}(0.78) \mathbf{1 0 0}$ & $25^{\mathrm{a}}(58) \mathbf{1 0 0}$ \\
\hline He et al., $2018 b$ & $\begin{array}{l}2015- \\
2016\end{array}$ & $\begin{array}{l}51 \text { children ( } 3-29 \text { months, average } \\
13 \text { months). } \\
\text { Two urine samples from two } \\
\text { consecutive days. } \\
\text { Not adjusted for specific gravity }\end{array}$ & $<0.01$ (n.r.) 33 & $<0.68$ (n.r.) 86 & 0.93 (n.r.) 96 & 3.3 (n.r.) 100 & & & 0.10 (n.r.) 75 & 1 (n.r.) 94 \\
\hline \multirow[t]{2}{*}{$\begin{array}{l}\text { Van den Eede et } \\
\text { al., } 2015 b\end{array}$} & $\begin{array}{l}2010- \\
2011\end{array}$ & $\begin{array}{l}\text { Adults and children } \\
\text { Pooled urine samples } \\
\text { Not adjusted for specific gravity } \\
\text { Campaign } 1: 28 \text { pools of } 7 \\
\text { individuals and } 44 \text { pools of } 7 \\
\text { individuals }\end{array}$ & - & - & n.r. $(9.43) 100$ & n.r. $(8.90) \mathbf{9 2}$ & n.r. (2.15)18 & - & n.r. $(0.53) 6$ & n.r. (727) 97 \\
\hline & $\begin{array}{l}2012- \\
2013\end{array}$ & $\begin{array}{l}\text { Campaign 2: } 23 \text { pools of } 100 \\
\text { individuals }\end{array}$ & - & - & n.r. (7.17) 100 & n.r. (3.41) 96 & n.r $(0.94) 4$ & - & n.a. 0 & n.r. (225) 100 \\
\hline \multicolumn{11}{|l|}{ Asia } \\
\hline $\begin{array}{l}\text { Chen et al., } 2018 \\
\text { China }\end{array}$ & 2015 & $\begin{array}{l}411 \text { children ( } 212 \text { aged } 8-12 \text { years } \\
\text { and } 199 \text { aged } 6-14 \text { years) } \\
\text { First morning void } \\
\text { Specific gravity adjusted }\end{array}$ & $1.04(86.9) 91$ & $0.15(3.11) 66$ & - & $0.05(4.73) 29$ & $0.12(2.67) 77$ & - . & $0.05(0.37) 84$ & $0.28(6.18) 99$ \\
\hline $\begin{array}{l}\text { Sun et al., } 2018 \\
\text { China, Shanghai }\end{array}$ & $\begin{array}{l}2016- \\
2017\end{array}$ & $\begin{array}{l}180 \text { participants ( } 130 \text { adults, } 27 \\
\text { students, and } 33 \text { children) } \\
\text { First morning void } \\
\text { Not adjusted for specific gravity }\end{array}$ & n.r. $(22.60) 5$ & n.r. (8.83) 16.7 & & n.r. (2.09) 21.1 & $\begin{array}{l}0.008(1.48) \\
\mathbf{5 1 . 7}\end{array}$ & & $\begin{array}{c}0.097(2.19) \\
\mathbf{6 8 . 3}\end{array}$ & $0.066(4.0) 67.8$ \\
\hline $\begin{array}{l}\text { Feng et al., } 2017 \\
\text { China, Shanghai }\end{array}$ & 2015 & $\begin{array}{l}23 \text { pregnant women } \\
\text { Spot urine } \\
\text { Specific gravity adjusted }\end{array}$ & - & - & - & $1.58(2.2) 17$ & - & - & - & $0.83(7.3) 100$ \\
\hline $\begin{array}{l}\text { Lu et al., } 2017 \\
\text { China }\end{array}$ & 2014 & $\begin{array}{l}221 \text { adults and children } \\
\text { First morning void } \\
\text { Not adjusted for specific gravity }\end{array}$ & $1.1(57) 71$ & $0.097(23) 56$ & - & $0.11(4.5) 76$ & $0.15(7.8) 99$ & - & $0.071(2.1) 93$ & $0.53(36) 100$ \\
\hline $\begin{array}{l}\text { Yoshida T et al., } \\
2012 \\
\text { Japan }\end{array}$ & n.r. & $\begin{array}{l}5 \text { individuals ( } 16-48 \text { years) } \\
\text { Spot urine } \\
\text { Not adjusted for specific gravity }\end{array}$ & - & - & - & - & $\begin{array}{c}<\mathrm{LOQ}(<\mathrm{LOQ}) \\
\mathbf{4 0}\end{array}$ & - & - & n.a. (9.8) 20 \\
\hline Europe & & & & & & & & & & \\
\hline
\end{tabular}




\begin{tabular}{|c|c|c|c|c|c|c|c|c|c|c|}
\hline $\begin{array}{l}\text { Larsson et al. } \\
2018 \\
\text { Sweden }\end{array}$ & 2015 & $\begin{array}{l}113 \text { children ( } 4 \text { years) } \\
\text { First morning void }\end{array}$ & & & & & & & & $1.8(35) \mathbf{1 0 0}$ \\
\hline $\begin{array}{l}\text { Völkel et al., } \\
2018 \\
\text { Germany }\end{array}$ & $\begin{array}{l}2011- \\
2012\end{array}$ & $\begin{array}{l}\text { Children ( } 20-80 \text { months) } \\
54 \text { urine samples } \\
\text { Spot urine } \\
\text { Not adjusted for specific gravity }\end{array}$ & & & & & & & 0.16 (n.r.) 80 & \\
\hline \multirow[t]{2}{*}{$\begin{array}{l}\text { Cequier et al., } \\
2015 \\
\text { Norway }\end{array}$} & 2012 & $\begin{array}{l}48 \text { mothers } \\
2 \text { to } 8 \text { samples over a period of } \\
24 \mathrm{~h} \text { ( } 244 \text { samples) } \\
\text { Specific gravity adjusted } \\
\text { Same population as Cequier et al., } \\
2014\end{array}$ & - & - & - & $0.08(2.1) \mathbf{5 2}$ & $<\operatorname{MDL}(0.35) 8$ & - & $\begin{array}{l}<\operatorname{MDL}(0.27) \\
<\mathbf{1}\end{array}$ & $0.63(60) 97$ \\
\hline & & $\begin{array}{l}54 \text { paired children (6-12 years, } \\
\text { median } 10 \text { years) } \\
2 \text { or } 3 \text { samples over a period of } \\
24 \text { h (112 samples) } \\
\text { Specific gravity adjusted }\end{array}$ & - & - & - & $0.23(3.3) 61$ & $<\operatorname{MDL}(1.0) 15$ & - & $<\operatorname{MDL}(1.0) 32$ & 1.0 (129) 97 \\
\hline \multirow[t]{2}{*}{$\begin{array}{l}\text { Cequier et al., } \\
2014\end{array}$} & n.r. & $\begin{array}{l}42 \text { mothers } \\
\text { Spot urine } \\
\text { Specific gravity adjusted }\end{array}$ & - & - & - & <LOQ (n.r.) 57 & $<\mathrm{LOQ}$ (n.r.) 5 & - & n.a. $\mathbf{0}$ & n.r. (n.r.) 100 \\
\hline & & $\begin{array}{l}42 \text { paired children } \\
\text { Spot urine } \\
\text { Specific gravity adjusted }\end{array}$ & - & - & - & n.r. (n.r.) 79 & <LOQ (n.r.) 14 & - & $<$ LOQ (n.r) 33 & n.r. (37) 100 \\
\hline $\begin{array}{l}\text { Fromme et al., } \\
2014 \\
\text { Germany }\end{array}$ & $\begin{array}{l}2011- \\
2012\end{array}$ & $\begin{array}{l}312 \text { children ( } 22-80 \text { months, mean } \\
54 \text { months) } \\
\text { Spot urine } \\
\text { Not adjusted for specific gravity }\end{array}$ & $0.2(13.1) 65$ & $<0.2(8.4) 21$ & - & - & $0.2(6.6) 71$ & - & $2.0(24.9) 90$ & $0.8(23.2) 91$ \\
\hline $\begin{array}{l}\text { Van den Eede et } \\
\text { al., 2013b } \\
\text { Belgium }\end{array}$ & n.r. & $\begin{array}{l}59 \text { adults ( } 23 \text { men and } 36 \text { women) } \\
\text { Spot urine } \\
\text { Not adjusted for specific gravity }\end{array}$ & n.r.(9.5) 27 & n.r (6.2) 3 & - & n.r (3.5) 25 & n.r (3.5) 5 & - & n.r $(7.0) 31$ & n.r (13) 93 \\
\hline $\begin{array}{l}\text { Reemstma et al., } \\
2011 \\
\text { Germany }\end{array}$ & n.r. & $\begin{array}{l}19 \text { urine samples from males and } \\
\text { females (14-85 years) } \\
\text { Spot urine } \\
\text { Not adjusted for specific gravity }\end{array}$ & - & - & - & - & - & - & - & 1.3 (n.r) n.r. \\
\hline \multicolumn{11}{|l|}{ North America } \\
\hline $\begin{array}{l}\text { Carignan et al., } \\
2018 \mathrm{a} \\
\text { USA } \\
\text { Massachusetts }\end{array}$ & $\begin{array}{l}2005 \text { to } \\
2015\end{array}$ & $\begin{array}{l}201 \text { men (whose partners were } \\
\text { undergoing in vitro fertilization) } \\
\text { Spot urine (1 sample) } \\
\text { Specific gravity adjusted }\end{array}$ & - & n.a. 0 & - & $0.46(12.39) 84$ & - & $0.21(3.60) 76$ & - & $0.57(8.54) 87$ \\
\hline $\begin{array}{l}\text { Carignan et al., } \\
2018 \mathrm{~b} \\
\text { USA } \\
\text { Massachusetts }\end{array}$ & $\begin{array}{l}2005 \text { to } \\
2015\end{array}$ & $\begin{array}{l}211 \text { women undergoing in vitro } \\
\text { fertilization } \\
\text { Spot urine ( } 1 \text { or } 2 \text { samples) } \\
\text { Specific gravity adjusted }\end{array}$ & - & n.a. 0 & - & $0.69(63.4) 87$ & - & & - & $0.75(616) 94$ \\
\hline $\begin{array}{l}\text { Deziel et al., } 2018 \\
\text { USA } \\
\text { Connecticut }\end{array}$ & $\begin{array}{l}2010- \\
2013\end{array}$ & $\begin{array}{l}200 \text { women ( } 100 \text { population- } \\
\text { based controls and } 100 \text { women } \\
\text { diagnosed with thyroid cancer in a }\end{array}$ & - & n.r. (n.r.) 44 & 0.19 (n.r.) 99 & 0.65 (n.r.) 97 & - & 2.35 (n.r.) 100 & - & 0.82 (n.r.) 97 \\
\hline
\end{tabular}




\begin{tabular}{|c|c|c|c|c|c|c|c|c|c|c|}
\hline & & $\begin{array}{l}\text { case-control study) } \\
\text { Specific gravity adjusted }\end{array}$ & & & & & & & & \\
\hline $\begin{array}{l}\text { Hoffman et al., } \\
2018 \\
\text { North Carolina }\end{array}$ & $\begin{array}{l}2002- \\
2005\end{array}$ & $\begin{array}{l}349 \text { pregnant women }(24- \\
30 \text { weeks) } \\
\text { Spot urine } \\
\text { Specific gravity adjusted }\end{array}$ & & n.r. (6.1) 49 & $0.42(98.0) 98$ & $1.85(140) 93$ & & $7.06(69.0) 99$ & & $1.31(112) 84$ \\
\hline Ingle et al., 2018 & $\begin{array}{l}2005- \\
2015\end{array}$ & $\begin{array}{l}220 \text { men } \\
\text { Spot urine ( } 1 \text { to } 5 \text { samples/man) } \\
\text { ( } 255 \text { samples) } \\
\text { Specific gravity adjusted }\end{array}$ & & & & $0.61(20.24) 85$ & & $\begin{array}{l}<\text { MDL. (4.08) } \\
\quad 67\end{array}$ & & $0.70(15.55) 86$ \\
\hline \multirow[t]{5}{*}{$\begin{array}{l}\text { Ospina et al., } \\
2018 \\
\text { National Survey } \\
\text { US population }\end{array}$} & $\begin{array}{l}2013- \\
2014\end{array}$ & $\begin{array}{l}2666 \text { spot urine samples, a } \\
\text { random 1/3 sample of participants } \\
\text { from the NHANES 2013-2014 } \\
\text { Not adjusted for specific } \\
\text { Age group: } 6 \text { year old and older }\end{array}$ & $0.39(110) 89$ & $0.16(46.7) 61$ & - & $0.88(169) 92$ & $0.25(70.3) 81$ & - & - & $0.82(193) 92$ \\
\hline & & Age group: $6-11$ years $(\mathrm{n}=421)$ & 0.66 (n.r.) n.r. & 0.25 (n.r.) n.r. & & 2.31 (n.r.) n.r. & 0.34 (n.r.) n.r. & - & - & 1.70 (n.r.) n.r. \\
\hline & & Age group: $12-19$ years $(n=427)$ & 0.57 (n.r.) n.r. & 0.16 (n.r.) n.r. & & 1.43 (n.r.) n.r. & 0.27 (n.r.) n.r. & - & - & 1.44 (n.r.) n.r. \\
\hline & & Age group: $20-59$ years $(n=1266)$ & 0.37 (n.r.) n.r. & 0.16 (n.r.) n.r. & & 0.85 (n.r.) n.r. & 0.22 (n.r.) n.r. & - & - & 0.73 (n.r.) n.r. \\
\hline & & $\begin{array}{l}\text { Age group: } 60 \text { years and older } \\
(\mathrm{n}=552)\end{array}$ & 0.30 (n.r.) n.r. & 0.13 (n.r.) n.r. & & 0.43 (n.r.) n.r. & 0.28 (n.r.) n.r. & - & - & 0.65 (n.r.) n.r. \\
\hline $\begin{array}{l}\text { Phillips et al., } \\
2018\end{array}$ & $\begin{array}{l}2014- \\
2016\end{array}$ & $\begin{array}{l}203 \text { children ( } 38-73 \text { months) } \\
\text { Three spot urine samples } \\
\text { collected over a } 48 \text {-h period } \\
\text { Specific gravity adjusted }\end{array}$ & & n.r. (31.9) 80 & n.r. (19.2) 97 & n.r. (80.7) 100 & & n.r. (61.5) 100 & & n.r. (50.9) 99 \\
\hline $\begin{array}{l}\text { Castorina et al., } \\
\text { 2017b } \\
\text { USA California }\end{array}$ & $\begin{array}{l}1999- \\
2000\end{array}$ & $\begin{array}{l}310 \text { pregnant women }(26 \pm 2.4 \\
\text { weeks) } \\
\text { Spot urine } \\
\text { Specific gravity adjusted }\end{array}$ & - & n.a. 0 & & $0.41(53.1) 77.7$ & - & $0.34(5.47) 71.6$ & - & $0.93(54.1) 79.4$ \\
\hline $\begin{array}{l}\text { Hoffman et al., } \\
2017 \text { a } \\
\text { USA North } \\
\text { Carolina }\end{array}$ & $\begin{array}{l}2001- \\
2006\end{array}$ & $\begin{array}{l}349 \text { pregnant women }(24-30 \\
\text { weeks) } \\
\text { Spot urine } \\
\text { Specific gravity adjusted }\end{array}$ & - & $0.7(6.1) 48.7$ & $0.4(98) 98.3$ & $1.9(140) 92.8$ & - & $7.1(69) 99.4$ & - & $1.3(112) 83.7$ \\
\hline $\begin{array}{l}\text { Preston et al. } \\
2017 \\
\text { USA } \\
\text { Massachusetts }\end{array}$ & $\begin{array}{l}2010- \\
2011\end{array}$ & $\begin{array}{l}51 \text { adults (office workers, } 26 \text { men } \\
\text { and } 25 \text { women) } \\
\text { Spot urine, three sampling rounds, } \\
\text { interval } 6 \text { months }\end{array}$ & & & & & & & $\begin{array}{c}\text { n.r. } \\
(0.17-142) \\
\text { n.r. }\end{array}$ & \\
\hline
\end{tabular}




\begin{tabular}{|c|c|c|c|c|c|c|c|c|c|c|}
\hline & & $\begin{array}{l}135 \text { samples } \\
\text { Specific gravity adjusted }\end{array}$ & & & & & & & & \\
\hline $\begin{array}{l}\text { Romano et al., } \\
2017 \\
\text { USA Rhode } \\
\text { Island }\end{array}$ & 2014 & $\begin{array}{l}58 \text { pregnant women (spot urine } \\
\text { samples collected at } 12,28 \text { and/or } \\
35 \text { weeks of gestation) } \\
\text { Specific gravity adjusted }\end{array}$ & 0.31 (n.r).74 & n.r (n.r.) 53 & - & 1.18 (n.r) 93 & n.r.(n.r.) 33 & - & - & 0.93 (n.r.) 95 \\
\hline \multirow[t]{2}{*}{$\begin{array}{l}\text { Thomas et al., } \\
2017 \\
\text { USA Washington }\end{array}$} & $\begin{array}{l}2012- \\
2014\end{array}$ & $\begin{array}{l}41 \text { children }(15-18 \text { months }) \\
\text { Spot urine } \\
\text { Specific gravity adjusted } \\
\text { Lab } 1 \\
\text { N=21 }\end{array}$ & - & - & - & $5.47(64.66) 95$ & - & $0.48(2.68) 81$ & - & $2.71(16.56) \mathbf{1 0 0}$ \\
\hline & & $\begin{array}{l}\text { Lab 2 } \\
\mathrm{N}=20\end{array}$ & - & - & - & $2.01(202.4) 85$ & - & - & - & $7.72(26.93) \mathbf{1 0 0}$ \\
\hline \multirow[t]{2}{*}{$\begin{array}{l}\text { Butt et al., } 2016 \\
\text { USA California }\end{array}$} & 2015 & $\begin{array}{l}28 \text { mothers } \\
\text { Spot urine } \\
\text { Specific gravity adjusted }\end{array}$ & - & n.a. (4.0) 11 & $2.4(104) 100$ & $2.8(14.3) \mathbf{1 0 0}$ & - & $2.0(14.8) 100$ & - & $1.2(3.5) \mathbf{1 0 0}$ \\
\hline & & $\begin{array}{l}33 \text { paired children ( } 2-70 \text { months, } \\
\text { mean } 44 \text { months) } \\
\text { Spot urine } \\
\text { Specific gravity adjusted }\end{array}$ & - & n.a. (3.4) 9 & $2.0(23.2) 100$ & $7.4(798) 100$ & - & $2.1(8.5) 100$ & - & $2.5(82.0) 100$ \\
\hline $\begin{array}{l}\text { Carignan et al., } \\
2016 \\
\text { Eastern United } \\
\text { States }\end{array}$ & 2012 & $\begin{array}{l}11 \text { female gymnasts (older than } \\
15 \text { years in age) } \\
\text { Several samplings on practice day } \\
\text { Specific gravity adjusted }\end{array}$ & - & - & - & $0.76(3.99) 100$ & - & - & - & $8.71(58.4) \mathbf{1 0 0}$ \\
\hline $\begin{array}{l}\text { Hammel et al., } \\
2016 \\
\text { USA North } \\
\text { Carolina }\end{array}$ & 2015 & $\begin{array}{l}40 \text { adults ( } 15 \text { men and } 25 \text { women) } \\
\text { First morning void on } 3 \text { separate } \\
\text { days } \\
\text { Specific gravity adjusted }\end{array}$ & - & n.a.(0.57) 18 & $1.12(16.99) 100$ & $\begin{array}{c}2.06(21.21) 100 \\
.\end{array}$ & - & - & - & $1.16(26.77) \mathbf{1 0 0}$ \\
\hline $\begin{array}{l}\text { Kosarac et al., } \\
2016 \\
\text { Canada }\end{array}$ & $\begin{array}{l}2010- \\
2012\end{array}$ & $\begin{array}{l}20 \text { pregnant women (second and } \\
\text { third trimester of pregnancy) and } \\
4 \text { post-partum women } \\
\text { Spot urine } \\
\text { Not adjusted for specific gravity }\end{array}$ & $0.46(1.25) 37$ & $0.46(2.41) 54$ & $\begin{array}{c}\text { n.a. }(0.53) 4 \\
\text { (free form, } \\
\text { without } \\
\text { enzymatic } \\
\text { deconjugation) }\end{array}$ & $0.26(1.77) 29$ & - & - & $<0.08(1.02) 17$ & $2.94(25.7) 92$ \\
\hline $\begin{array}{l}\text { Petropoulou et al., } \\
2016 \\
\text { USA California }\end{array}$ & n.r. & $\begin{array}{l}13 \text { adults ( } 8 \text { women and } 5 \text { men) } \\
\text { Spot urine } \\
\text { Not adjusted for specific gravity }\end{array}$ & $1.3(15.0) 100$ & $0.3(3.5) \mathbf{1 0 0}$ & - & $2.4(7.3) 100$ & - & - & - & $1.5(5.6) 100$ \\
\hline $\begin{array}{l}\text { Hoffman et al., } \\
\text { 2015a } \\
\text { USA North } \\
\text { Carolina }\end{array}$ & $\begin{array}{l}2014- \\
2015\end{array}$ & $\begin{array}{l}43 \text { children ( } 2-18 \text { months, mean } \\
7.9 \text { months) } \\
\text { Spot urine } \\
\text { Specific gravity adjusted }\end{array}$ & & n.r. (7.5) 19 & & n.r. (541) 100 & & n.r. (6.1) 35 & & n.r. (26.5) 93 \\
\hline $\begin{array}{l}\text { Hoffman et al., } \\
2015 \text { b } \\
\text { USA North } \\
\text { Carolina }\end{array}$ & 2012 & $\begin{array}{l}53 \text { adults ( } 26 \text { men and } 27 \text { women) } \\
\text { Spot urine } \\
\text { Specific gravity adjusted }\end{array}$ & - & - & - & n.r. (4.46) 83 & - & - & - & n.r. (9.09) 91 \\
\hline $\begin{array}{l}\text { Su et al., } 2015 \\
\text { Canada }\end{array}$ & 2014 & $\begin{array}{l}12 \text { urine samples from } 4 \\
\text { individuals } \\
\text { Spot urine, } 3 \text { consecutive days } \\
\text { Not adjusted for specific gravity }\end{array}$ & n.r. (12.33) 100 & n.r. $(0.68) 42$ & - & n.r. (1.17) 83 & $\begin{array}{l}\text { n.r. }(<\mathrm{MDL} \text { or } \\
\quad<\mathrm{LOQ}) \mathbf{4 2}\end{array}$ & - & $<\mathrm{MDL}$ & n.r. (1.29) 75 \\
\hline
\end{tabular}




\begin{tabular}{|c|c|c|c|c|c|c|c|c|c|c|}
\hline $\begin{array}{l}\text { Butt et al., } 2014 \\
\text { USA New Jersey }\end{array}$ & $\begin{array}{l}2013- \\
2014\end{array}$ & $\begin{array}{l}19 \text { mothers } \\
\text { Spot urine } \\
\text { Specific gravity adjusted }\end{array}$ & - & n.r. (0.64) 14 & - & n.r. (11.0) 100 & - & n.r. (2.3) 100 & - & n.r. (68.7) 95 \\
\hline & & $\begin{array}{l}23 \text { paired children (1-5 years) } \\
\text { Spot urine } \\
\text { Specific gravity adjusted }\end{array}$ & - & n.r. $(0.46) 4$ & - & n.r. (251) 100 & - & n.r. (10.1) 92 & - & n.r. (140) 100 \\
\hline $\begin{array}{l}\text { Dodson et al., } \\
2014 \\
\text { USA California }\end{array}$ & 2011 & $\begin{array}{l}16 \text { adults } \\
\text { Spot urine } \\
\text { Not adjustment for specific } \\
\text { gravity. }\end{array}$ & $0.63(2.1) 75$ & n.a. $(0.97) 31$ & - & $0.09(3.9) 94$ & $0.11(0.45) \mathbf{5 6}$ & - & n.a. $(0.71) 12$ & $0.44(6.8) 62$ \\
\hline $\begin{array}{l}\text { Hoffman et al., } \\
2014 \\
\text { USA North } \\
\text { Carolina }\end{array}$ & $\begin{array}{l}2011- \\
2012\end{array}$ & $\begin{array}{l}8 \text { pregnant women } \\
\left(18^{\text {th }} \text { and } 28^{\text {th }} \text { week of pregnancy: }\right. \\
24-\mathrm{h} \text { urine and first morning } \\
\text { voids. After birth of child: } 1 \text { spot } \\
\text { urine }) \\
39 \text { urine samples } \\
\text { Not adjusted for specific gravity }\end{array}$ & - & - & - & $1.1(19.9) 97$ & - & - & - & $1.6(37.3) 97$ \\
\hline $\begin{array}{l}\text { Meeker et al., } \\
2013 \\
\text { USA } \\
\text { Massachusetts }\end{array}$ & $\begin{array}{l}2002- \\
2007\end{array}$ & $\begin{array}{l}45 \text { men } \\
\text { Spot urine } \\
\text { Presumably specific gravity } \\
\text { adjusted }\end{array}$ & - & - & - & $0.12(25.0) 91$ & - & - & - & $0.27(9.84) 96$ \\
\hline $\begin{array}{l}\text { Cooper et al., } \\
2011 \\
\text { North America }\end{array}$ & n.r. & $\begin{array}{l}3 \text { adults } \\
9 \text { urine samples } \\
\text { Spot urine } \\
\text { Specific gravity adjusted }\end{array}$ & - & - & - & $0.37(3.47) \mathbf{1 0 0}$ & - & - & - & $1.81(63.8) \mathbf{1 0 0}$ \\
\hline
\end{tabular}

${ }^{a}$ In most studies, the metabolite method limit of detection (MLOD) was in the range of 0.01-0.6 $\mu \mathrm{g} / \mathrm{l}$, depending on the method used. It was lower for BDCIPP and BBOEP (3 ng/l) in the study of He et al., 2018a) and for BCEP, BDCIPP, and DPHP in the study of Sun et al., 2018 (2-5 ng/l). The MLOD was in the range of 1.0 to $2.7 \mu \mathrm{g} / \mathrm{l}$ for BCIPP in the study of Hammel et al. (2016), for BCIPP and DPHP in the study of Kosarac et al (2016), and for DNBP and DPHP in the study of Yoshida et al. (2012). The limit of quantification (LOQ) of BCEP, BCIPP, BDCIPP, and

DNBP was in the range of 0.8-1.6 $\mu \mathrm{g} / \mathrm{l}$ in the study of Chen et al. (2018). The LOQs of BCEP and BCIPP were 1.2, and 3.7 $\mu \mathrm{g} / \mathrm{l}$, respectively, in the study of Van den Eede et al.

(2013b). The LOQ of DNBP and DPHP were 2.3, and $2.6 \mu \mathrm{g} / \mathrm{l}$, respectively, in the study of Yoshida et al. (2012).

a Mean

n.r. Not reported.

n.a. Not applicable

- Not analyzed 
Table 4. Urinary concentrations of the principal metabolites of PEFRs in workers ( $\mu \mathrm{g} / \mathrm{L})$.

$50^{\text {th }}$ percentile $(\max ) \% \geq$ limit of detection (LOD)

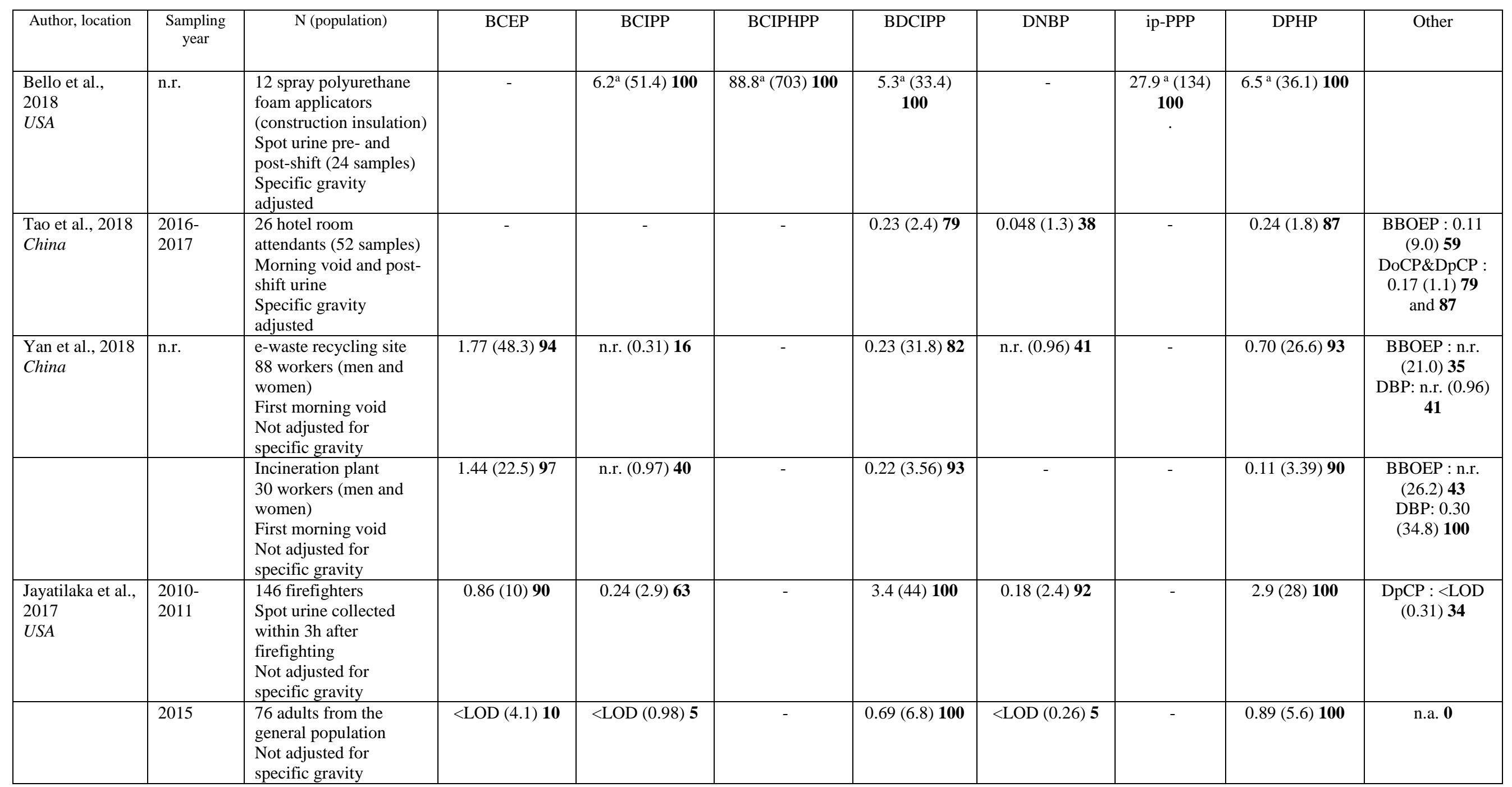




\begin{tabular}{|c|c|c|c|c|c|c|c|c|c|c|}
\hline $\begin{array}{l}\text { Schindler et al., } \\
2014 \\
\text { Germany }\end{array}$ & n.r. & $\begin{array}{l}5 \text { aircraft maintenance } \\
\text { technicians } \\
\text { Spot urine } \\
\text { Not adjusted for } \\
\text { specific gravity } \\
\text { Preshift/Postshift }\end{array}$ & $\begin{array}{c}0.5 / 0.3 \\
(1.7) /(0.5) \mathbf{1 0 0}\end{array}$ & $\begin{array}{c}0.2 / 0.2 \\
(0.3) /(0.3) \mathbf{7 0}\end{array}$ & - & - & $\begin{array}{c}12.5 / 23.5 \\
(37.2) /(51.6) \\
\mathbf{1 0 0}\end{array}$ & - & $\begin{array}{c}2.9 / 3.5 \\
(7.4) /(7.9) \mathbf{1 0 0}\end{array}$ & $\begin{array}{c}\text { DoP, DmCP, or } \\
\text { DpCP < LOD } \\
\text { (i.e. } 0.5)\end{array}$ \\
\hline $\begin{array}{l}\text { Carignan et al., } \\
2013 \\
\text { USA }\end{array}$ & 2009 & $\begin{array}{l}29 \text { office workers } \\
\text { (women and men) } \\
\text { Spot urine during } \\
\text { afternoon of a work day } \\
\text { Specific gravity } \\
\text { adjusted }\end{array}$ & - & - & - & $\begin{array}{c}408^{\mathrm{a}} \cdot(1760) \\
\mathbf{1 0 0}\end{array}$ & - & - & - & \\
\hline \multirow[t]{2}{*}{$\begin{array}{l}\text { Schindler et al., } \\
2013,2009 \mathrm{a} \\
\text { and b } \\
\text { (Anderson, } \\
\text { 2015; Weiss et } \\
\text { al., 2015) } \\
\text { Germany } \\
\end{array}$} & n.r. & $\begin{array}{l}332 \text { urine samples from } \\
\text { air crews } \\
\text { Spot urine collected } \\
\text { within } 12 \mathrm{~h} \text { after } \\
\text { exposure } \\
\text { Not adjusted for } \\
\text { specific gravity }\end{array}$ & $0.33(20.3) 82$ & $0.16(6.87) 65$ & - & - & $0.28(9.72) \mathbf{1 0 0}$ & - & $\begin{array}{c}1.10(302) \\
100\end{array}$ & $\begin{array}{c}\text { DoP: }<\text { LOD } \\
\text { (i.e. } 0.5) \\
\text { DmCP: }<0.5 b \\
(0.62) \mathbf{0 . 3} \\
\text { DpCP }<\text { LOD } \\
(0.55) \mathbf{0 . 3}\end{array}$ \\
\hline & & $\begin{array}{l}30 \text { individuals from the } \\
\text { general population (11- } \\
68 \text { years) } \\
\text { Spot urine } \\
\text { Not adjusted for } \\
\text { specific gravity }\end{array}$ & $<0.1^{\mathrm{b}}(27.5) \mathbf{5 0}$ & $<0.25^{\mathrm{b}}(0.85) \mathbf{1 2}$ & - & - & $<0.25^{\mathrm{b}}(0.26) 4$ & - & $0.52(5.47) 68$ & $\begin{array}{l}\text { DoP, DmCP, or } \\
\text { DpCP < LOD } \\
\text { (i.e. } 0.5 \text { ) }\end{array}$ \\
\hline
\end{tabular}

${ }^{\mathrm{a}}$ Geometric mean

${ }^{b}$ Limit of detection (LOD)

n.r. Not reported

- Not analyzed 
Table 5 PEFR concentrations in hair and nails (ng/g dry weight)

$50^{\text {th }}$ percentile (range) $\% \geq$ limit of detection

\begin{tabular}{|c|c|c|c|c|c|c|c|c|c|c|}
\hline $\begin{array}{c}\text { Author } \\
\text { Location } \\
\text { N (population) } \\
\text { Sampling year }\end{array}$ & & TCEP & TCIPP & TDCIPP & TNBP & TEHP & EHDPP & TPHP & TBOEP & Other \\
\hline \multicolumn{11}{|l|}{ Europe } \\
\hline \multirow[t]{3}{*}{$\begin{array}{l}\text { Alves et al., } 2017 \\
\text { Belgium } \\
\text { A woman and a } \\
\text { man } \\
\text { Year n.r. }\end{array}$} & $\begin{array}{l}\text { Hair (scalp } \\
\text { segment, one } \\
\text { sample) }\end{array}$ & & & & & & & & & $\begin{array}{c}\text { DPHP } \\
\text { Womanc: } 0.25 \\
\text { Manc: } 0.23\end{array}$ \\
\hline & $\begin{array}{l}\text { Fingernails } \\
\text { (4 or five } \\
\text { collections over } \\
2 \text { months }\end{array}$ & & & & & & & & & $\begin{array}{c}\text { Womanc: } 40002 \\
\text { Manc: } 80.5\end{array}$ \\
\hline & $\begin{array}{l}\text { Toenails } \\
\text { ( } 4 \text { or five } \\
\text { collections over } \\
2 \text { months } \\
\end{array}$ & & & & & & & & & $\begin{array}{l}\text { Womanc: } 6815 \\
\text { Manc: } 18.5\end{array}$ \\
\hline \multirow{2}{*}{$\begin{array}{l}\text { Kurcharska et al., } \\
2015 \mathrm{a} \\
\text { Norway } \\
48 \text { mothers and } \\
\text { their } 54 \text { children (6- } \\
12 \text { year old) } \\
2012\end{array}$} & $\begin{array}{l}\text { Hair (scalp } \\
\text { segment) } \\
\underline{\text { Mothers }}\end{array}$ & $\begin{array}{c}72 \\
\left(<33^{\mathrm{a}}-163\right) \\
16\end{array}$ & & $\begin{array}{c}30 \\
\left(<9^{a}-3744\right) \\
91\end{array}$ & $\begin{array}{c}22 \\
(5-672) \\
100\end{array}$ & $\begin{array}{c}12 \\
\left(<1^{\mathrm{a}}-53\right) \\
96\end{array}$ & $\begin{array}{c}27 \\
(5-265) \\
\mathbf{1 0 0}\end{array}$ & $\begin{array}{c}52 \\
(5-1256) \\
\mathbf{1 0 0}\end{array}$ & $\begin{array}{c}65 \\
(14-1253) \\
\mathbf{1 0 0}\end{array}$ & $\begin{array}{c}\frac{\mathrm{TCP}}{8} \\
\left(<2^{\mathrm{a}-134)}\right. \\
78\end{array}$ \\
\hline & $\begin{array}{l}\text { Hair (scalp } \\
\text { segment) } \\
\text { Children }\end{array}$ & $\begin{array}{c}59 \\
\left(<33^{\mathrm{a}}-118\right) \\
\mathbf{2 6}\end{array}$ & & $\begin{array}{c}31 \\
\left(<9^{\mathrm{a}}-2698\right) \\
\mathbf{9 2} \\
n . r .\end{array}$ & $\begin{array}{c}11 \\
(3-150) \\
\mathbf{1 0 0} \\
n . r .\end{array}$ & $\begin{array}{c}8 \\
\left(<1^{\mathrm{a}}-118\right) \\
90 \\
n . r .\end{array}$ & $\begin{array}{c}21 \\
\left(2^{\mathrm{a}}-346\right) \\
\mathbf{1 0 0} \\
n . r .\end{array}$ & $\begin{array}{c}63 \\
(6-363) \\
\mathbf{1 0 0} \\
n . r .\end{array}$ & $\begin{array}{c}318 \\
(34-2411) \\
\mathbf{1 0 0} \\
n . r .\end{array}$ & $\begin{array}{c}\frac{\mathrm{TCP}}{8} \\
\left(<2^{\mathrm{a}}-74\right) \\
62\end{array}$ \\
\hline $\begin{array}{l}\text { Martin et al., } \\
2015 \\
\text { Germany } \\
4 \text { women }\end{array}$ & $\begin{array}{l}\text { Hair (scalp } \\
\text { segment) }\end{array}$ & & $\begin{array}{c}n . r .(0.18- \\
1.70) 100\end{array}$ & & $\mathbf{0}$ & & & $\begin{array}{c}n . r .(0.10-0.91) \\
\mathbf{1 0 0}\end{array}$ & & \\
\hline
\end{tabular}




\begin{tabular}{|c|c|c|c|c|c|c|c|c|c|c|}
\hline Year n.r & & & & & & & & & & \\
\hline $\begin{array}{l}\text { Kurcharska et al., } \\
2014 \\
\text { Belgium } \\
20 \text { adults } \\
\text { Year n.r. }\end{array}$ & Hair & $\begin{array}{c}55 \\
(34-404) \\
\mathbf{7 0}\end{array}$ & & $\begin{array}{c}42 \\
(10-2969) \\
\mathbf{9 5}\end{array}$ & $\begin{array}{c}32 \\
(7-5032) \\
\mathbf{9 5}\end{array}$ & $\begin{array}{c}10 \\
(2-322) \\
\mathbf{7 5}\end{array}$ & $\begin{array}{c}15 \\
(5-105) \\
\mathbf{1 0 0}\end{array}$ & $\begin{array}{c}59 \\
(7-237) \\
\mathbf{1 0 0}\end{array}$ & $\begin{array}{c}37 \\
(7-338) \\
\mathbf{1 0 0}\end{array}$ & $\begin{array}{c}\frac{\mathrm{TCP}^{\mathrm{b}}}{5} \\
(3-73) \\
\mathbf{6 5}\end{array}$ \\
\hline \multicolumn{11}{|l|}{ China } \\
\hline $\begin{array}{l}\text { Qiao et al., } 2016 \\
49 \text { adults ( } 27 \text { man } \\
\text { and } 22 \text { woman) } \\
2014\end{array}$ & $\begin{array}{l}\text { Hair (two } \\
\text { segments) }\end{array}$ & $\begin{array}{c}3.61 \\
\left(<3.50^{\mathrm{a}}-64.9\right) \\
\mathbf{5 7}\end{array}$ & $\begin{array}{c}43.9 \\
\left(<6.53^{\mathrm{a}}-141\right) \\
98\end{array}$ & $\begin{array}{c}4.14 \\
\left(<1.04^{\mathrm{a}}-73.8\right) \\
\mathbf{8 6}\end{array}$ & $\begin{array}{c}3.30 \\
\left(<0.61^{\mathrm{a}}-25.4\right) \\
\mathbf{9 8}\end{array}$ & $\begin{array}{c}24.1 \\
\left(<0.05^{\mathrm{a}}-151\right) \\
\mathbf{9 8}\end{array}$ & $\begin{array}{c}11.8 \\
\left(5.78^{\mathrm{a}}-78\right) \\
\mathbf{7 1}\end{array}$ & $\begin{array}{c}20.5 \\
\left(<1.43^{\mathrm{a}}-352\right) \\
\mathbf{8 4}\end{array}$ & & $\begin{array}{c}\frac{\text { TiPP }}{2.43} \\
\left(<0.81^{\mathrm{a}}-12.4\right) \\
94\end{array}$ \\
\hline \multicolumn{11}{|l|}{ United States } \\
\hline \multirow{3}{*}{$\begin{array}{l}\text { Liu et al., } 2016 \\
\text { Indiana } \\
50 \text { adults } \\
2014\end{array}$} & $\begin{array}{l}\text { Hair (scalp } \\
\text { segment) }\end{array}$ & $\begin{array}{c}240 \\
(60-2740) \\
\mathbf{6 8}\end{array}$ & $\begin{array}{c}450 \\
(100-9840) \\
\mathbf{8 8}\end{array}$ & $\begin{array}{c}360 \\
(70-10490) \\
\mathbf{9 0}\end{array}$ & & & & $\begin{array}{c}220 \\
(70-4710) \\
\mathbf{9 8}\end{array}$ & & \\
\hline & Fingernail & $\begin{array}{c}190 \\
(93-1860) \\
\mathbf{2 0}\end{array}$ & $\begin{array}{c}220 \\
(74-2410) \\
\mathbf{3 6}\end{array}$ & $\begin{array}{c}300 \\
(90-1410) \\
66\end{array}$ & & & & $\begin{array}{c}370 \\
(110-59800) \\
\mathbf{7 4}\end{array}$ & & \\
\hline & Toenail & $\begin{array}{c}150 \\
(100-150) \\
\mathbf{8}\end{array}$ & $\begin{array}{c}230 \\
(90-5150) \\
\mathbf{3 2}\end{array}$ & $\begin{array}{c}230 \\
(75-2300) \\
\mathbf{5 0}\end{array}$ & & & & $\begin{array}{c}1080 \\
(54-232900) \\
\mathbf{7 4}\end{array}$ & & \\
\hline \multirow[t]{2}{*}{$\begin{array}{l}\text { Liu et al., } 2015 \\
\text { Indiana } \\
5 \text { adults } \\
\text { Year n.r. }\end{array}$} & $\begin{array}{l}\text { Hair (scalp } \\
\text { segment) }\end{array}$ & $\begin{array}{c}n . r . \\
\left(<75^{\mathrm{a}}-1950\right) \\
\mathbf{8 0}\end{array}$ & $\begin{array}{c}n . r . \\
(290-1190) \\
\mathbf{1 0 0}\end{array}$ & $\begin{array}{c}n . r . \\
\left(<75^{\text {a }-970)}\right. \\
\mathbf{8 0}\end{array}$ & & & & $\begin{array}{c}n . r . \\
(76-310) \\
\mathbf{1 0 0} \\
r .\end{array}$ & & \\
\hline & Fingernail & $\begin{array}{c}n . r . \\
\left(<150^{\mathrm{a}}-<150\right) \\
\mathbf{0}\end{array}$ & $\begin{array}{c}n . r . \\
\left(<150^{\mathrm{a}}-<150\right) \\
\mathbf{0}\end{array}$ & $\begin{array}{c}n . r . \\
(280-630) \\
\mathbf{1 0 0}\end{array}$ & & & & $\begin{array}{c}n . r . \\
\left(<150^{\mathrm{a}-17500)}\right. \\
\mathbf{1 0 0}\end{array}$ & & \\
\hline
\end{tabular}

${ }^{a}$ Limit of quantification (LOQ)

${ }^{\mathrm{b}}$ Sum of isomers

c Average level

n.r. Not reported 
S1. Chemical structure of the main PEFR metabolites

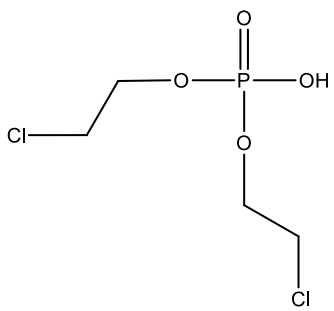

BECP

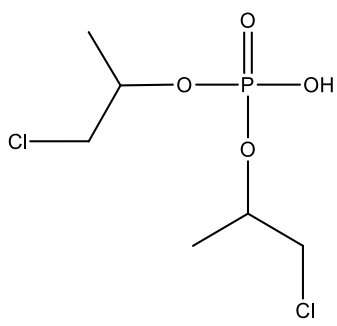

BCIPP

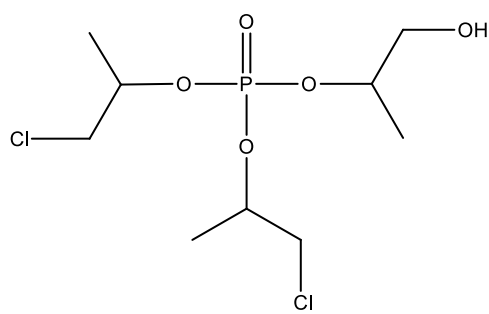

BCIPHPP<smiles>O=P(O)(OC(CCl)CCl)OC(CCl)CCl</smiles>

BDCIPP

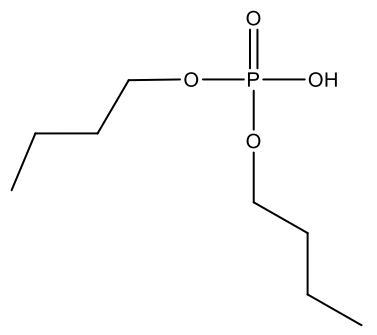

DBNP

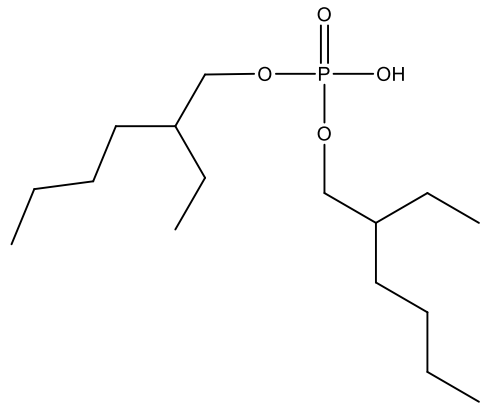

BEHP 

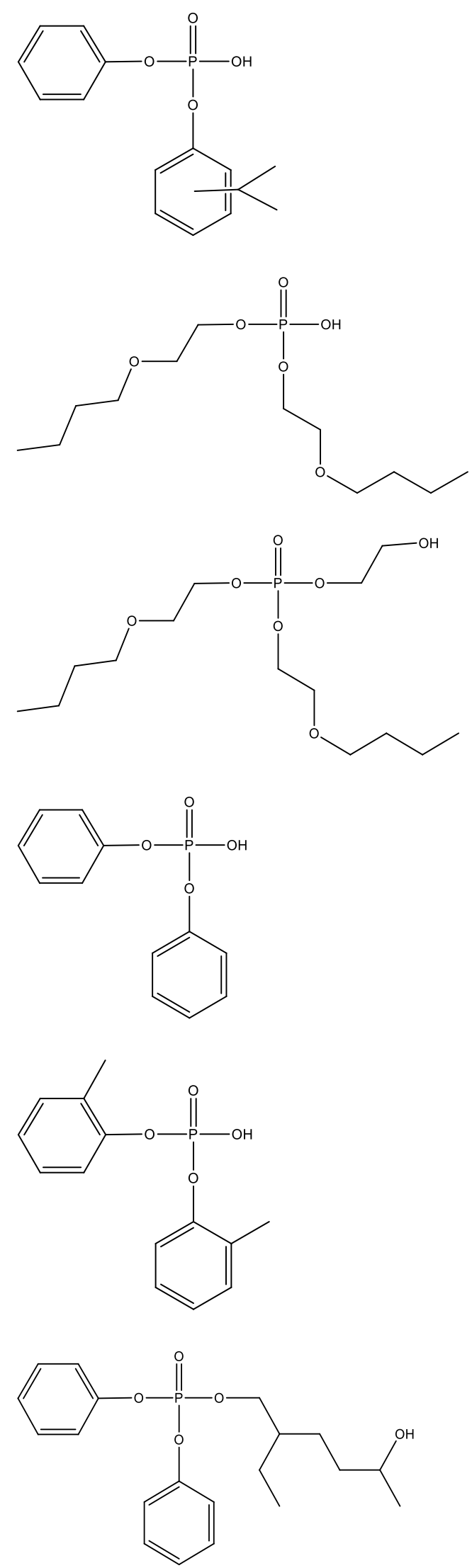

ip-PPP

BBOEP

BBOEHEP

\section{DPHP}

\section{DoCP}

5-OH-EHDPHP 